\title{
Covid19 pandemic as a further driver of water scarcity in Africa
}

\author{
Alberto Boretti $\mathbb{B}$
}

Published online: 25 August 2020

(C) Springer Nature B.V. 2020

\begin{abstract}
Population growth, even if coupled to economic growth, and resources, were already on a collision course, especially in Africa. The 2019 United Nations World Water Development Report provided a dramatic status of world water, however without questioning the main drivers of an imminent water crisis, that were unbounded, unequal, economic, and population growth, within the context of reducing resources in a finite world. Despite the report was a small step forward in awareness, still, it was not proposing satisfactory remedies. With business-asusual, without acting on the drivers of water scarcity, regional water crises were inevitable in the next 3 decades, starting from Africa. Constrained by political, financial, and energy burdens, the technological improvements that have helped humanity to deal with the increased demand for water, food, and energy over the last 70 years, were likely not enough to avoid the water crisis. On top of forecast is the Covid19 pandemic. Coronavirus cases are (August 4, 2020) $18,446,065$ and fatalities are 697,202 worldwide, and still growing. The containment measures enforced for Covid19 infection following the examples in the United Kingdom have already produced significant damage to the world economy. This will limit social expenditures in general, and the expenditures for the water issue in
\end{abstract}

\section{A. Boretti $(\square)$}

Prince Mohammad Bin Fahd University, Al Khobar, Saudi Arabia

e-mail: a.a.boretti@gmail.com particular. The water crisis will consequently become worse in the next months, with consequences still difficult to predict. This will be true especially for Africa, where the main problem has always been poverty. There is the opportunity of significant health, food, and water crisis, especially in Africa. While the concepts of washing hands and social distancing that are difficult to apply haven't produce so far major issues with the Covid19 outbreak in Africa, borders closure, restrictions on movement, and more poverty will translate in a lack of food and water potentially much more worrying than the virus spreading.

Keywords Water scarcity - Energy availability . Global economy · Governance change · Technological advances $\cdot$ Food challenge $\cdot$ Covid19

\section{Introduction}

During the last 70 years, the world has experienced unprecedented, dramatic growth, characterized by a sharply increasing population and economy, accompanied by a generally increasing life span and quality of life, all phased with the growing use of energy, food, and water (ourworldindata.org). Unbounded growth in a finite world of finite resources is however impossible, as there is the certainty that growth and resources will eventually collide (Boulding 1973). Before the Covid19 outbreak, water scarcity was more worrying than food shortages (Boretti and Rosa 2019). 
The water crisis is indirectly related to energy and financial crises (Boretti and Rosa 2019). The energy problem was also a growing concern. Situation at the local level, especially in Africa, were expected to be much worse than the global average (Boretti and Rosa 2019).

When the first draft of this paper was written, there were practically no Covid19 cases in Africa. Then, things have changed, there are now more Covid19 cases in Africa, but still nothing similar to what happened in Western Europe and other parts of the world (https://ourworldindata.org). This reduced direct effect of the pandemic makes even stronger the case, supported in this paper, that Covid19 will affect water scarcity in Africa through more complex global and local mechanisms related to freedom of movements, economy, poverty, and supply of good and services, than simply the increased use of water for sanitation because of the washing hands to prevent the spreading of the virus. In particular, the containment measures will impact more than the virus itself, also affecting water scarcity. The epidemiological models such as those promoted in the United Kingdom (Ferguson et al. 2020) to introduce lockdowns have been proven to be wrong (Boretti 2020b). Wrong models in Western Europe cannot be correct in Africa. Additionally, global economic downturns will affect Africa.

The United Kingdom has adopted harsher containment measures than other countries such as the Netherlands or Sweden based on the wrong models. They had more, rather than less, fatalities, as this is not the major issue (Boretti 2020c). Protection of the vulnerable for age or comorbidities, especially in the nurses' homes, the most affected by the virus fatalities, seems to have made a difference in Western Europe (Boretti 2020c).

From a demographic perspective, the average age in Western Europe is much higher than Africa, same of life expectancy. Restrictions above certain levels to the healthy population, at least in Western Europe, have been counterproductive (Boretti 2020c). There has been no further benefiting from looking down large sectors of the healthy population or forcing people to wear masks while forgetting the protection of the sick for other morbidities or aged (Boretti 2020c).

The lesson we learned so far, is that Covid19 is more infective and more lethal in countries where this pandemic has been used for political reasons, and also where there has been more focus on limiting the movements of the healthy population, rather than preventing the infection of the vulnerable (Boretti 2020c). The mortality of Covid19 has been mostly centered on those vulnerable for age or comorbidities (Boretti 2020c). Statistically (data from http:// ourwoldindata.org), the worst countries in the world for Covid19 infection fatalities are Belgium and the United Kingdom, and there are reasons for this (Boretti 2020c). Africa should not follow their paths for what concerns containment measures, as the lockdowns can be counterproductive.

Figure 1 is an up-to-date statistic of Covid19 cases and fatalities (from http://ourwoldindata.org). The daily confirmed new coronavirus cases are not a reliable parameter to compare nations, as the number of tests per 1000 people dramatically varies across countries. Without tests, there are no cases. With more tests, there are more cases for a similar intensity of the outbreak. The number of tests for Africa is mostly not even reported. The number of cases for Africa is generally less than in Western Europe, but without having uniform testing, this result is not reliable.

To be mentioned, the PCR test is everything except the "gold standard" in testing for Covid19, as it does not make any difference in between new and old coronaviruses, and does not provide any indication of the severity of the infection. The test grows exponentially small amounts of DNA looking for "viral sequences" also amplifying contaminations. Looking for partial viral sequences, not whole genomes, identification of a single pathogen is troublesome. The PCR only tells if the viral sequence is related to the family of coronaviruses. The PCR test also does not give the viral load. Having only a few viruses does not cause illness or likely spreading. Having many viruses causes sickness and significant spreading. Thus, the number of infections is not particularly indicative. From an epidemiological perspective, it would be better to understand who has antibodies from Covid19 infection, i.e. how many people are immune from reinfection, or at least have been infected already, but almost nobody has this number.

The number of deaths per million is the most trustworthy indicator of the severity of the Covid19 outbreak so far (Boretti 2020b, c). It has a delay versus the spreading of the virus. Africa has been so far the less affected continent of the world. The below graph 
Total COVID-19 tests per 1,000 people, Jul 26, 2020

The figures shown relate to the closest date for which we have data, with a maximum of 10 days' difference.
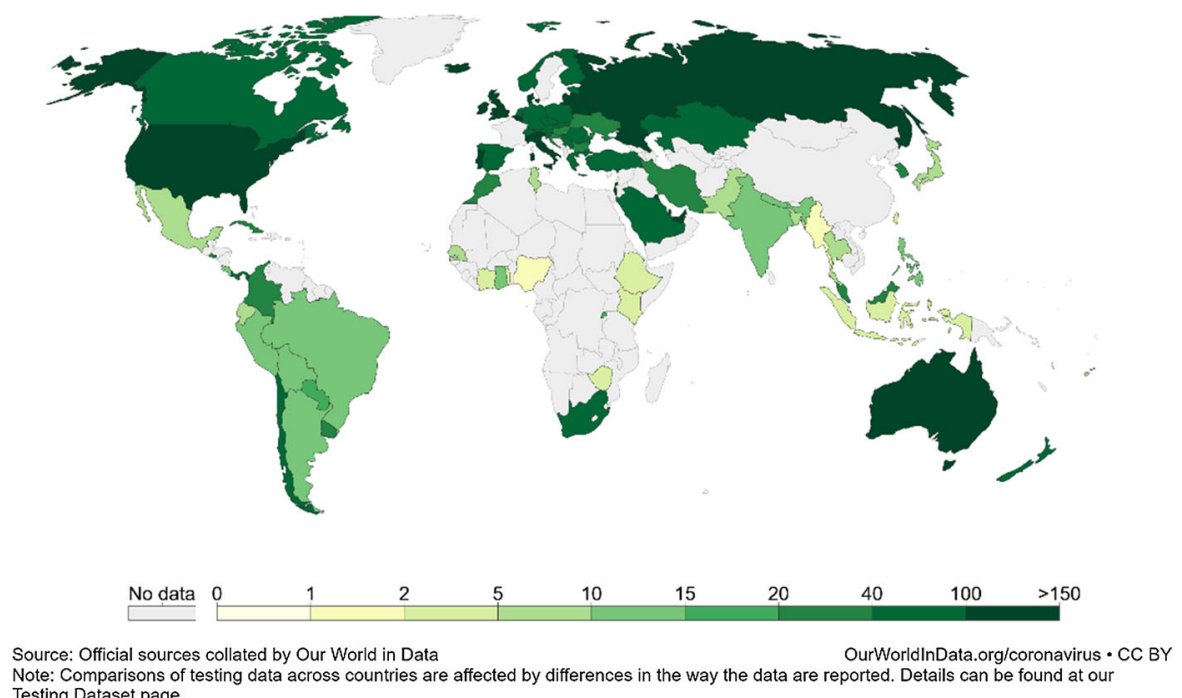
Testing Dataset page.

Total confirmed COVID-19 cases per million people, Jul 28, 2020 The number of confirmed cases is lower than the number of total cases. The main reason for this is limited testing.

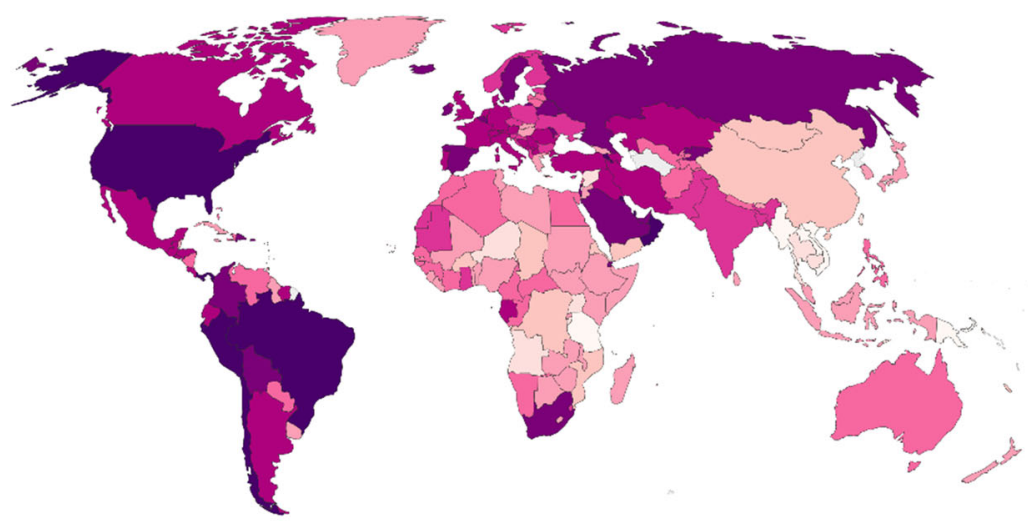

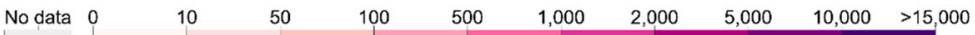

Source: European CDC - Situation Update Worldwide - Last updated 28 July, 11:07 (London time) OurWorldlnData.org/coronavirus • CC BY

Fig. 1 Covid19 pandemic around the world. Africa has been so far the less affected continent by Covid19 fatalities, despite the much worse conditions for sanitation and health services. Images from https://ourworldindata.org

needs to be coupled to the trajectories of Covid19 infection to understand which countries have "bent" the curve.

While Belgium achieved a peak of daily fatalities above 25 per million (7-days rolling average) and the United Kingdom had a peak of daily fatalities of almost 15 per million (7-days rolling average), apart from South Africa and Swaziland that have growing cases now at above 4 and 1 daily fatalities per million (7-days rolling average), every other country of Africa are still below 0.5 daily fatalities per million (7-days rolling average). 
Total confirmed COVID-19 deaths per million people, Jul 28, 2020

Limited testing and challenges in the attribution of the cause of death means that the number of confirmed deaths may not be an accurate count of the true total number of deaths from COVID-19.
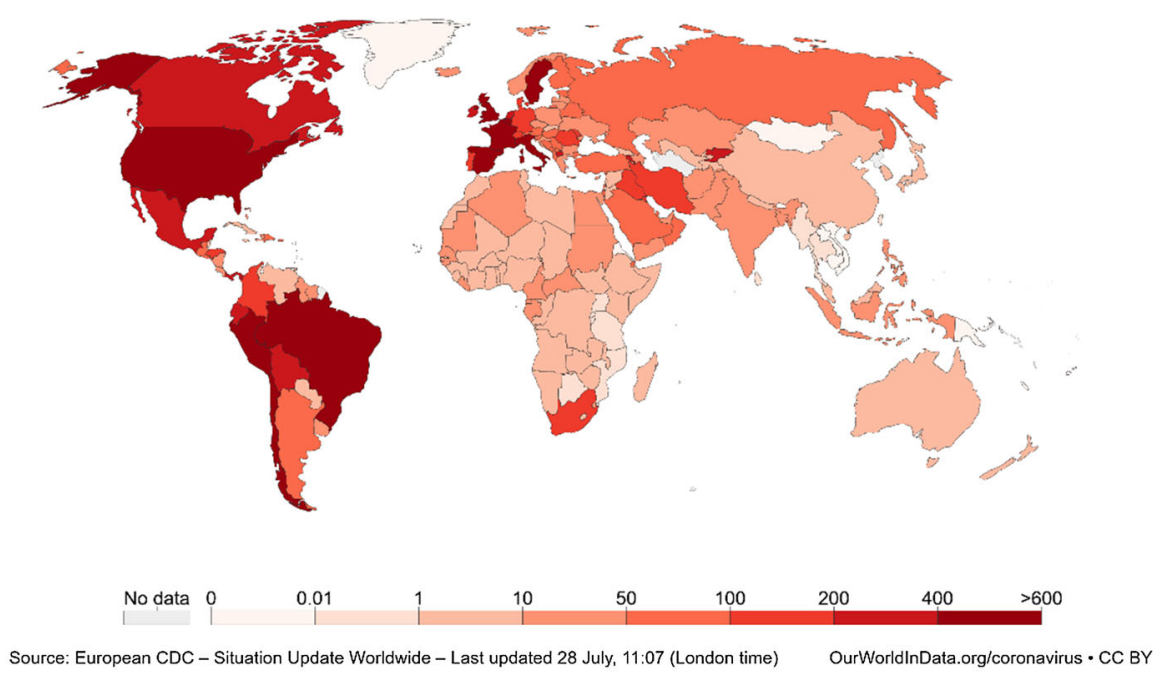

Daily confirmed COVID-19 deaths per million, rolling 7-day average Limited testing and challenges in the attribution of the cause of death means that the number of confirmed deaths may not be an accurate count of the true number of deaths from COVID-19.

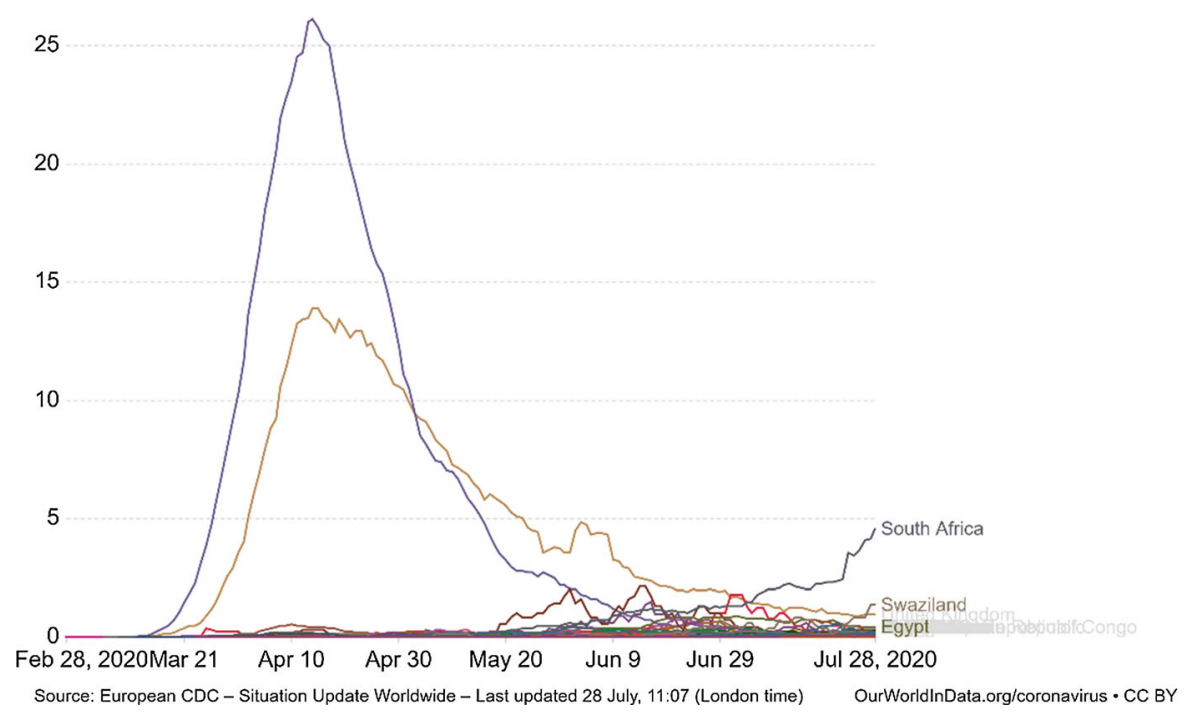

Fig. 1 continued

It may be argued that the fatalities of Africa are underrated, or that the fatalities of Western Europe are overrated, with many cases of default attribution to Covid19 of fatalities produced by other causes. However, for what is shown in Fig. 1, it seems that not having been used as a political weapon, Covid19 has produced so far much less direct fatalities in Africa than everywhere else, despite the medical background of Africa is certainly the worse on Earth.

This is the background information from which to move to analyze the water-Covid19 nexus in Africa. The work aims to discuss Covid19 pandemic as a further driver of water scarcity in Africa. 
Daily confirmed COVID-19 deaths per million, rolling 7-day average Limited testing and challenges in the attribution of the cause of death means that the number of confirmed deaths may not be an accurate count of the true number of deaths from COVID-19.

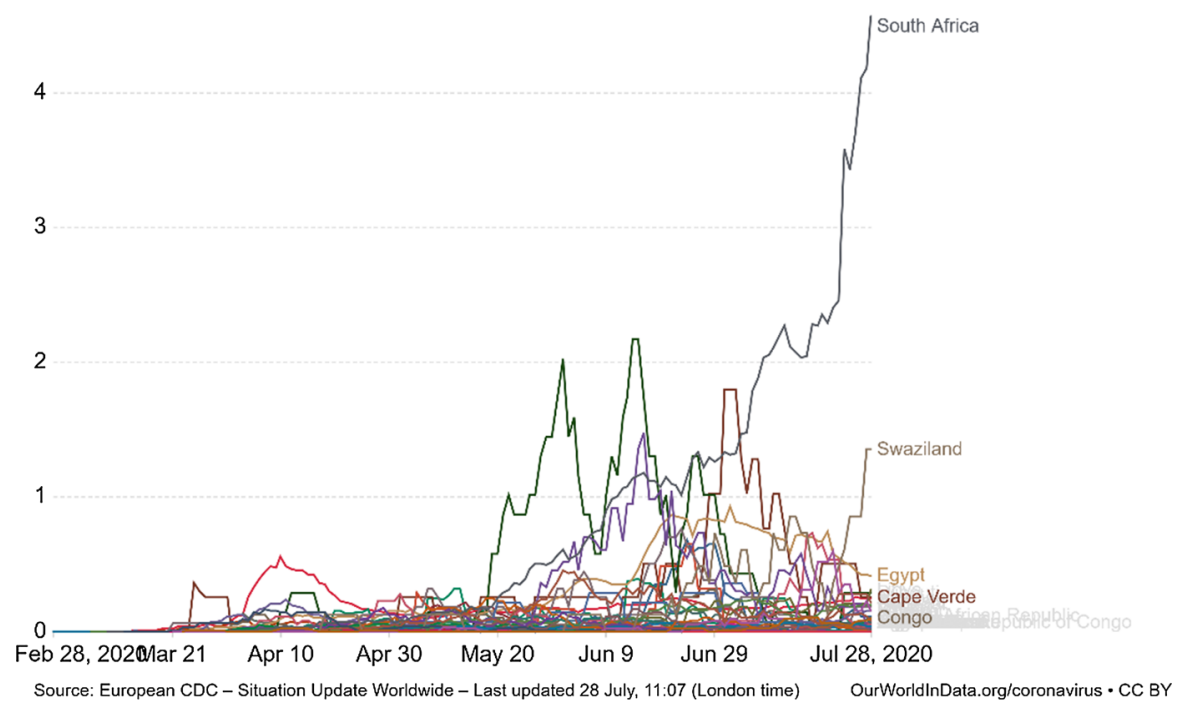

Daily confirmed COVID-19 deaths per million, rolling 7-day average Limited testing and challenges in the attribution of the cause of death means that the number of confirmed deaths may not be an accurate count of the true number of deaths from COVID-19.

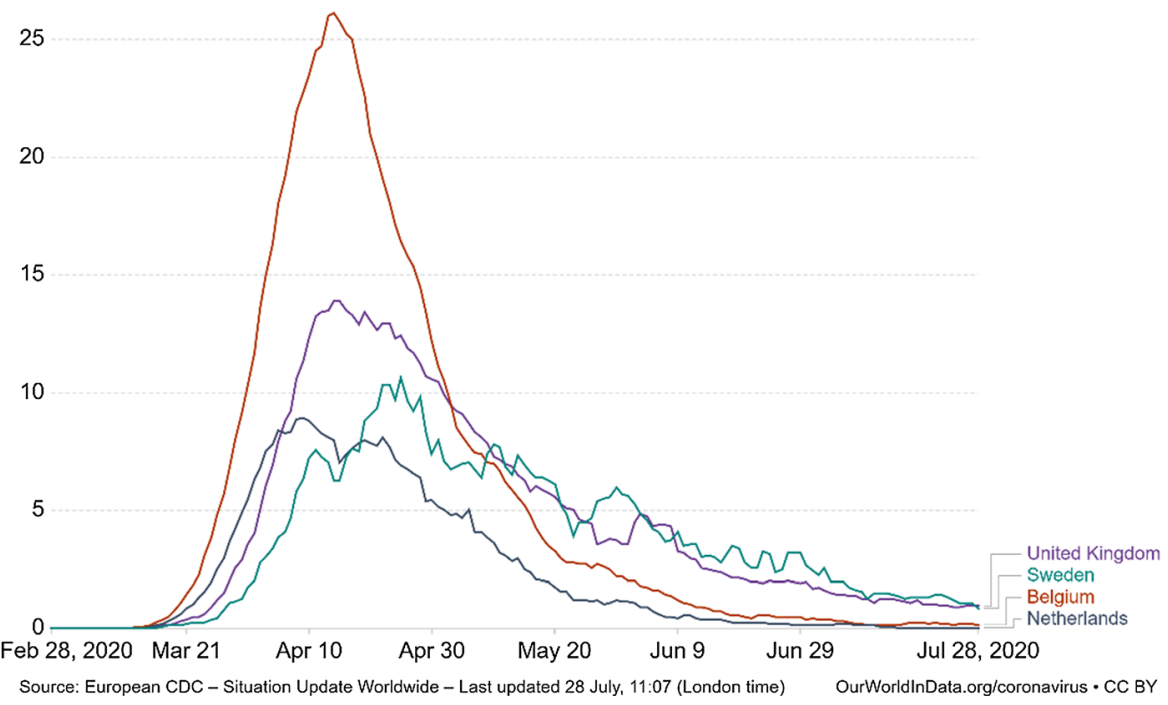

Fig. 1 continued

\section{Water-Covid19 nexus in Africa}

The major effect of Covid19 on water scarcity in Africa is not through the increased demand for sanitary uses of water, but the indirect effect on the economy, poverty, freedom of movement, inequality, and scarcity. Few works have discussed the waterCovid19 nexus in Africa from the specific point of view that washing hands and enforcing hygiene is more difficult where water is scarce, and thus more fatalities are expected for Africa because of the lack of water.

Anim and Ofori-Asenso (2020) notices as access to water are the key to infectious disease control and prevention. Thus, limited access creates a challenge for transmission control. Anim and Ofori-Asenso 
(2020) concludes that inequalities in access to safe water can make spreading easier.

Amuakwa-Mensah et al. (2020) discusses the increased practice of hands washing in the wave of the Covid19 spreading.

Haddout et al. (2020a) discussed water scarcity in the slums, noticing that this may affect negatively hygiene.

Haddout et al. (2020b) discusses the insufficient water for washing likely to worsen the coronavirus outbreak in the poorest nations.

From what has been measured so far, Fig. 1, washing hands more or less easily had minimal impact on the spreading of the virus in Africa. The number of fatalities for African nations has been much less than those in other countries such as Belgium or the United Kingdom, where there is no water scarcity, and additionally, for those infected and in need of medical attention, the health system is generally much more funded and effective. Thus, Covid19 is not, or at least not only, a problem of washing hands.

It is the arguing of this work than the Covid19 epidemic across the globe will do more damage in Africa indirectly, through the global recession, increased local poverty, lockdowns, practical access to food, water and health services, for the mechanisms proposed hereafter for what concerns water, that directly through the spreading of the virus, that could be exacerbated from not washing hands enough, but also depends on many other factors still far from being fully understood, at least in the literature.

\section{Desalination in Africa}

The recent work (Takouleu 2020) has finally pointed out as the major issue with water scarcity in Africa is primarily economical, as energy-intensive and expensive water desalination and purification, and distribution, could solve most of the water issues for Africa. Also the health system and the quality of services in general in Africa are an economical problem.

In Saudi Arabia, there is no river or lake, and all the tap water is from desalination (smartwatermagazine.com 2020). Desalination water has not only domestic uses, but it is also used for agriculture and farming with significant production (smartwatermagazine.com 2020) and industrial uses.
Fig. 2 a World total primary energy supply according to the IEA (International Energy Agency 2019). The latest 2017 contribution by combustion fuels and nuclear is $95.65 \%$ of the total. The TPES demand has increased by $59 \%$ since 1990 , or $1.8 \%$ per year. b World total population according to www. worldometers.info. The latest population (2020 forecast) is $7,794,798,739$. The population of 1955 was only $2,773,019,936$. The annual growth rate has been reducing from $2.1-2 \%$ of 1970-1975 to the latest $1.2-1.1 \%$ of 2015-2019. c World GDP according to www.worldometers.info. The latest GDP (2017) is US $\$ 80,250,107,912,599$ (inflation-adjusted). It was US\$38,015,667,938,023 in $1990(+111 \%)$. The latest (2017) growth rate is $3.15 \%$. The GDP per capita has increased from US $\$ 7136$ of 1990 to the latest (2017) US $\$ 10,632(+49 \%)$. The latest (2017) GPD per capita growth rate is $1.12 \%$

Africa has many arid lands even close to the coast where desalination could help considerably, if only they could afford (Takouleu 2020). Also, regions far from the coast could benefit if infrastructure could be affordable (Takouleu 2020). This is a problem of availability of financial means first, and then the availability of energy next. Desalination is expensive and energy-intensive. The first problem of Africa since the nominal end of colonialism is financial independence. Poverty is the major issue of Africa (Patel 2018).

Many African countries are now understanding that water cannot be afforded without money.

As written in Takouleu (2020), "Several African countries are increasingly turning to non-conventional water resources such as desalination. This new policy in favour of desalination stems from the scarcity of surface and groundwater resources in some parts of the continent." (Takouleu 2020) properly concludes. " it is not absolutely necessary to have access to the sea to desalinate water. Even so, the 35 African countries with a seafront are obviously the first concerned by the desalination option: Algeria, Angola, Benin, Cameroon, Cape Verde, Comoros, Côte d'Ivoire, Democratic Republic of Congo, Djibouti, Egypt, Eritrea, Equatorial Guinea, Gabon, Gambia, Ghana, Guinea Bissau, Kenya, Liberia, Libya, Madagascar, Mauritania, Morocco, Mozambique, Namibia, Nigeria, Republic of Congo, Sao Tome and Principe, Senegal, Sierra Leone, Somalia, South Africa, Sudan, Tanzania, Togo and Tunisia."

Hence, it is important to realize the relevance of desalination, and water infrastructure, and the role of energy, wealth and financial independence, for the 

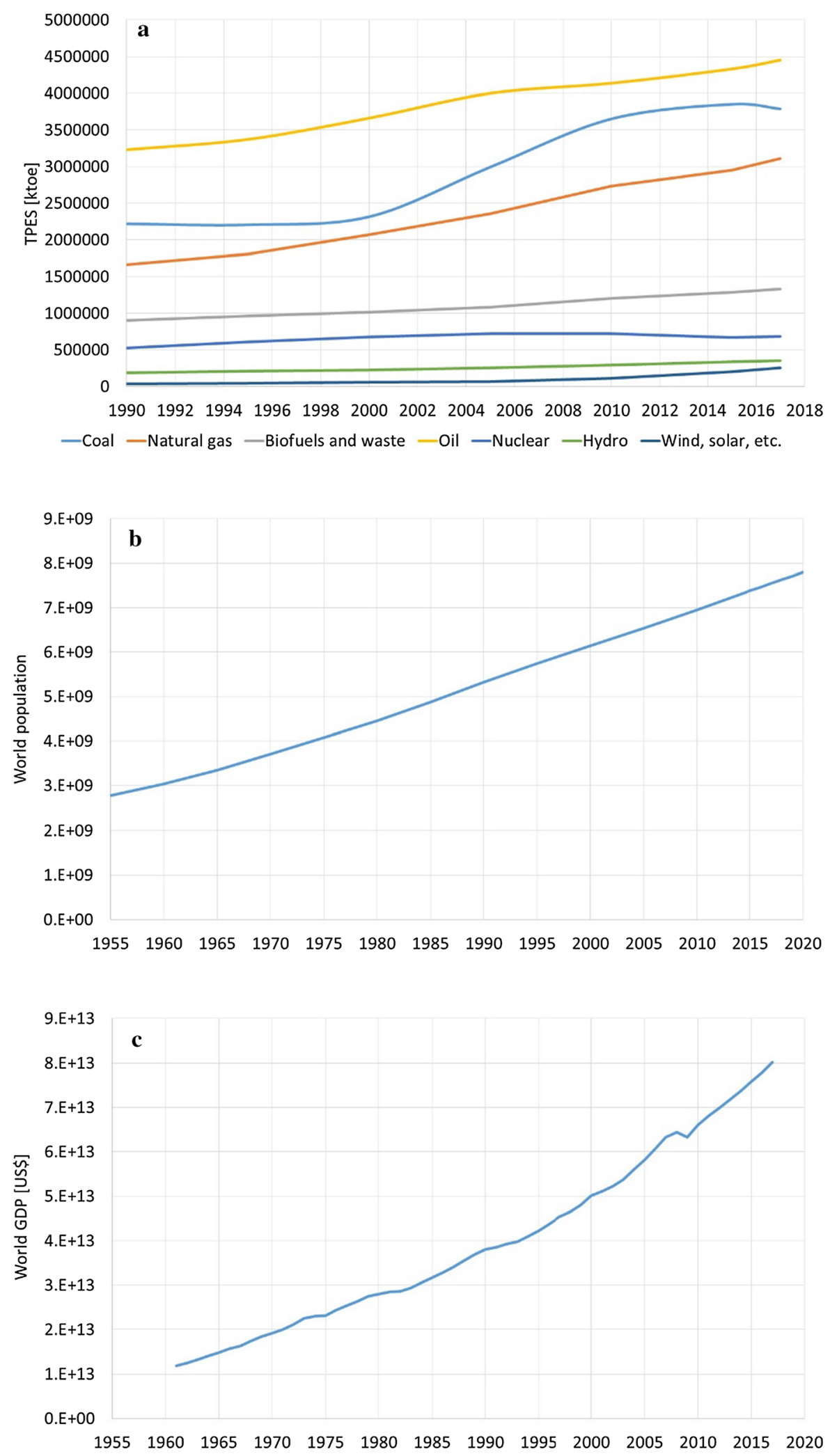
future of water in Africa. Every improvement of these criteria will results in improvement of water availability. Opposite, every decline. Covid19 may act as a declining factor for all the three criteria.

\section{Global growth in population, economy and energy demand}

The trend in global population, economy and energy demand is shown in Fig. 2.

Figure 2a presents the world's total primary energy supply (TPES) according to the International Energy Agency (IEA 2019). The TPES of 2017 has been $1.4 \times 10^{7}$ kilotons of oil equivalent (ktoe), up from the $8.77 \times 10^{6}$ ktoe of $1990(+59 \%)$. The TPES of 2017 was covered more than $90 \%$ by combustion fuels (oil, coal, natural gas, biofuels, and waste). Their share has been stable above $90 \%$ over the period of observation, oscillating from a maximum of $91.5 \%$ and a minimum of $90.4 \%$, up to the latest $90.7 \%$. If we prefer to separate biofuels and waste, the share of oil, coal, natural gas has been stable above $80 \%$, oscillating from a maximum of $81.9 \%$ and a minimum of $80.2 \%$, up to the latest $81.2 \%$. There has been a tendency to increase the share of hydro, that has increased from the $2.1 \%$ of 1990 to the latest $2.5 \%$, and wind, solar, etc., that has increased from the $0.4 \%$ of 1990 to the latest $1.8 \%$, that is reflected in the reduction of nuclear, from the $6 \%$ of 1990 to the latest $4.9 \%$. The pledges to reduce consumption of combustion fuels, while also targeting nuclear energy, make it difficult to understand how the presently $95.65 \%$ contribution could be provided in an expanding world during the next decades.

Figure $2 \mathrm{~b}$ presents the world's total population according to www.worldometers.info. The latest population (2020 forecast) is 7,794,798,739. The population of 1955 was only $2,773,019,936$. The annual growth rate has been reducing from $2.1-2 \%$ of $1970-1975$ to the latest $1.2-1.1 \%$ of $2015-2019$ that is however still substantial. 1990 to 2017 , the world population increased from 5,327,231,061 to $7,547,858,925(+41.7 \%)$. While $34 \%$ of the population was living in cities in 1960, the share of the urban population in 2020 is projected to exceed $56 \%$.

Figure 2c presents the world GDP according to www.worldometers.info. The latest GDP (2017) is US\$80,250,107,912,599 (inflation-adjusted). It was
US $\$ 38,015,667,938,023$ in $1990(+111 \%)$. The GDP has increased much more than the population. The latest (2017) growth rate is $3.14 \%$. Since 1961, the average growth rate has been $3.50 \%$, with a maximum of $6.66 \%$ and a minimum of $-1.73 \%$. Depurated of the effect of population growth, the GDP per capita has increased from US\$7,136 of 1990 to the latest (2017) US\$10,632 (+ 49\%).

Thus, water scarcity in Africa is a problem of local poverty, being exacerbated by the growing population and the growing inequalities, and being alleviated mostly by local and minimally by global, economic growth, still significant in a context of global and local growth in the use of energy and the economy.

\section{Global and local water scarcity}

It is in this context of growing population and economy, and growing demand for energy, with uncertainties in the future energy supply, as well as growing demand for food and water, with limited resources, that the discussion of a likely water crisis triggered by the Covid19 pandemic must be located.

Water scarcity is already an issue in many parts of the world and especially in Africa (United Nations Water 2019). The growth of the population and the economy has translated into increased demand for water and food, which is water twice, as agricultural demand is much larger than municipal and industrial demand for water (United Nations Water 2019).

While the total amount of water on Earth has not changed significantly, there has been a disruption of the hydrological cycle resulting from many human activities, including building dams, changing land use, building cities and roads, or mining (United Nations Water 2019). Additionally, the increased freshwater use has been coupled to the reduction of many aquifers for withdrawals exceeding replenishment, as well as pollution (United Nations Water 2019). There were already signs that the rate of growth of population and economy, which are the drivers of water scarcity in a world of limited resources that are also shrinking, was not sustainable and could have led to a dramatic water crisis (Boretti and Rosa 2019). If water scarcity was likely the most imminent problem humanity will face, it was hard to understand from United Nations Water (2019) or United Nations Water (2018) when and how precisely a water crisis could have affected the global 
population and economy, and what should have been done to avoid this occurrence.

According to United Nations Water (2019), safe and clean water was unavailable in some form to $30 \%$ of the world population. By 2025, $20 \%$ of the world population is expected to experience water scarcity, and $50 \%$ of the world population is expected to face water-stressed conditions. By 2050, the share of those experiencing water scarcity and water-stressed conditions is expected to rise further in a world of a population estimated to reach 9.7 billion people.

After having proposed these dramatic numbers, it was however unclear how they could have an impact on life expectancy and net population growth, that up to the time were increasing constantly together. United Nations Water (2019), same as the previous reports such as United Nations Water (2018), does not mention any practical measure to prevent the water crisis. Not enough emphasis is placed on the drivers of the scarcity, which are excessive population and economic growth and inequality (Boretti and Rosa 2019).

It is unclear what the water scarcity parameters proposed in United Nations Water (2019) meant in terms of quality of life, life expectancy, and growth in the number of people on earth, as well as of the GDP, both global and per-capita, locally and globally. It is difficult to understand what was the real threat to humanity in a water crisis, and what should have been done, from the reading of United Nations Water (2019).

If a water crisis is imminent and has very large impacts on humanity, why then possible solutions to this crisis are only euphemized into politically correct slogans, such as "adopt nature-inspired solutions" (dry toilets and such) in United Nations Water (2018), or "make sure nobody is left behind" in United Nations Water (2019)? These incongruences prompt the question whether water scarcity is a narrative or a genuine, imminent, serious threat to the humanity. If it is real, as it seems, then why United Nations Water (2019) or United Nations Water (2018) carefully omit to mention the evident drivers of the scarcity and fail to propose any serious remedy to tackle the problem from the roots?

The recent emergence of the Covid19 outbreak as a major threat to humanity is now prompting the question of how this pandemic will impact the water crisis, and the food crisis, especially in Africa, where the conditions are much worse than the world average. Water demand has always grown in combination with economic and population growth. Water scarcity is a major issue especially in Africa, and especially since the last 25 years, that has been characterized by the continuous growth of the local economy, together with the population (United Nations Water 2019). What may happen when water demand increases in a continent that is becoming poorer and may suffer of significant restriction is a worrying question.

The number of people migrating from Africa was significant, but this was a small fraction of the huge population growth (United Nations conference for trade and development 2018). However, remittals by migrants helped the local economy considerably, perhaps assisting the boom. Does an increase in the population of Africa during a local and global downward economy translate into everything but sustainable water and food scarcity? If there is global and local economic growth, at least in principle there could be the means to at least alleviate or mitigate water or food scarcity. May restriction of movement of people, posing not only a halt to the recent mass migration, but also damaging the economy, and leaving many without food and water, make things much worse? Here we try to answer these questions, within the admitted limits of the conjectures about the future developments of the Covid19 outbreak nobody knows yet when and how will finish.

\section{World economy and governance}

The gross domestic product (GDP) per capita is a wrong parameter to represent the ability of a nation to address societal issues. Developed countries have a reduced ability to help their citizens as well as the citizens of developing countries because of their growing debt (Mbaye and Moreno Badia 2019). The way the pandemic is being managed globally will result in huge debt for every country, with limited resources to help domestic and foreign citizens.

The world governance has been questioned for the response given so far to the pandemic. Major doubts have been cast about the advice the world governments received from the World Health Organization (WHO), that in January was negating the opportunity of human-to-human transmission of Covid19 (Birchall 2020), in February was considering unnecessary travel 
restrictions (Birchall 2020), but in March declared the pandemic (Birchall 2020), and in April declared antibodies from having been infected from Covid19 do not protect from reinfection (while the antibodies produced by a vaccine are protective) (WHO 2020a). Last, but not least, the ban of the use of chloroquine/ hydroxychloroquine after a flawed paper in the Lancet then retracted, removed after the retraction, (RT.com 2020) but then reintroduced after a similarly flawed study was not even published.

The major donor to the WHO is a "charity" controlled by one individual (WHO 2019b). This charity supports, directly and indirectly, the organization with more funds than the United States or The United Kingdom governments, or the government of Germany, that have otherwise reduced their relative support. The same "charity" is also the overwhelming donor to the GAVI vaccine alliance (http://en. wikipedia.org/wiki/GAVI) suggesting immunization policies across the world and especially in developing countries, an activity that ought to be supported by governments through more proper channels. The present WHO director is a past board member of GAVI (2017). If the only way out from the Covid 19 pandemic has to be a working vaccine, the economic damage of unsustainable restrictions enforced until a safe and efficient vaccine will be made available, will be huge.

Water development projects in Africa are already underfunded as a result of the reduced amount of funds allocated by the governments of developed countries given their growing debt. This will worsen with the Covid19 downturn. The link between debt and water scarcity in Africa is clear. The population of developing countries is growing, as is their water demand. This would necessitate expensive water projects to at least mitigate if not fully address the issue. The funds for these projects are not available. Water scarcity is therefore increasing. Further shrinking government budgets due to Covid-19 and further reduced funding for international development from Organization for Economic Cooperation and Development (OECD) countries will impact water after Covid19.

\section{International cooperation}

Within the water politics literature, there are general assumptions that scarcity is a product of growing water use linked to population and economic development, but linked to poor management and governance, and climate change, for which somebody else is guilty. Also within this literature, there are ideas that there is enough water to meet human needs, our problems are management, governance, finance, and political will, again by somebody else. Unfortunately, this is part of a dystopia very well predicted in George Orwell's "Nineteen Eighty-Four: A Novel", where a tiny minority controls the vast majority of people on Earth that are defocused on something else than their needs. Objectively, there are fewer funds available to theoretically address water scarcity, and these funds are also improperly used, translating to very little improvements in water security.

United Nations Water (2018) did not only recommend dry toilets, but also other solutions that could help to alleviate scarcity. The report details ecosystem services programs in Latin America which increase the supply and quality of fresh water to cities, as well as a range of solutions for water for agriculture, the world's biggest water user. However, these reports ignore the fact that colonialism and capitalism have evolved via controlling nations, for example in Latin America, or Africa, through the monetary fund rather than through military dictatorships (CADTM 2002).

Corporations, investment funds, and banks of rich countries exercise considerable power over the lives of billions of people through their control over institutions of global governance with the International Monetary Fund only one of these institutions (CADTM 2002). The relationship of poor countries with the International Monetary Fund is similar to the relationship between a poor patient badly ill and a very expensive doctor that he/she cannot afford (CADTM 2002). The patient goes to the doctor for treatment. The doctor prescribes a very expensive controversial treatment. The patient consents to the treatment, even if he/she knows that he/she cannot afford it. The patient then develops terrible side effects also discovering the original problem has worsened. The poor patient is more ill and more desperate and needs more help from the very expensive doctor (CADTM 2002).

\section{Future water scarcity without Covid19}

The world population is increasing, as is the use of freshwater (United Nations Water 2018, 2019; Boretti 
and Rosa 2019). This growth is accompanied by the growth in the consumption of fossil fuels (International Energy Agency 2019), the anthropogenic emission of carbon dioxide (International Energy Agency 2019), the global consumption of energy (International Energy Agency 2019), the gross domestic product (GDP) total and per capita (www. worldometers.info), and the world's debt per person (Mbaye and Moreno Badia 2019). Pollution of freshwater, salinization of aquifers, and reduction of the aquifers is also growing (Boretti and Rosa 2019). The increasing water demand is on a collision course with the reduced availability of clean water (Boretti and Rosa 2019).

The increasing GDP per capita is a favorable aspect, as this allow resource recuperation, development of novel resources (i.e. desalination), and enforcement of mitigation strategies. On the other hand, the increasing world debt per person is a negative aspect, as debts limit the spending opportunities. Similarly worrying is the planned reduction of the use of combustion fuels also targeting nuclear energy, with the present contribution by hydro, wind, and solar only $4.35 \%$ of a growing world total primary supply (International Energy Agency 2019). Adaptation strategies for water scarcity, desalination, and purification, as well as improved infrastructures, have significant economic and energetic costs.

The fact that the economy was giving conflicting signals before the Covid19 outbreak, as GDP and debt per capita were both growing, adds tensions, similarly to a possible lack of energy, now exacerbated by the pandemic.

\section{Trends in water demand, population and GDP}

Growing population, economic expansion, and transforming consumption patterns have so far increased global freshwater use (United Nations Water 2018, 2019). The water scarcity issue is already relevant at the regional level in some areas. In many areas, it was expected to become increasingly significant in the next few decades (United Nations Water 2019). Surprisingly, water scarcity was supposed to grow more especially in the areas already affected by water scarcity, but where the population was also supposed to grow more, namely Africa.
Figures 3 and 4 present water withdrawal, GDP and population data.

Figure $3 \mathrm{a}$ and $\mathrm{b}$ present global water withdrawals, global population, and population of selected countries, and global GDP per capita 1950-2050. Figure $4 a-c$ show the geographical differences of GDP per capita, water withdrawal per capita, and population growth rate. Figure $4 d$ proposes water stress. This parameter is a measure of water withdrawals as a share of the water resources.

Besides scarcity, pollution and salinization of aquifers are additional problems. Scarcity at a local level is much worse than scarcity at regional or even country level (United Nations Water 2019). This displaces people, adding to economic reasons, resource availability, and conflicts, a reason to migrate.

According to United Nations Water (2019), the world's water use is rising and is expected to rise at the same rate until 2050. Today more than 2 billion people experience water stress and more than 4 billion people experience severe water scarcity at least one month per year. More than 3 billion people do not have access to the water safe to drink, and more than 5 billion people do not have access to sanitation services. More than 1 billion people are practicing open defecation.

These global figures do not distinguish the fate of the poor, masking significant inequities at local and global levels, with differences growing rather than reducing. This is particularly true in Africa.

The situation in Africa is different from the situation of Europe or North America. Clean water shortage was already a major issue in 7.7 billion people world expected to further grow by 2050 when the world population will reach between 9.4 and 10.2 billion, likely 9.7 billion.

In 2050 two-thirds of this population will be living in cities, and mostly along the coasts (United Nations Water 2019). Desalination could be, if not a solution, certainly a mitigation strategy, but desalination is expensive economically and energetically.

Most of the population growth is expected from developing countries. In Africa, the population will more than double. Some countries with present challenging water supplies will experience a population growth over a 100-years' time window above 2000\% (Boretti and Rosa 2019).

Most of the predictions suggest more than $50 \%$ of the global population will live in areas that are water- 

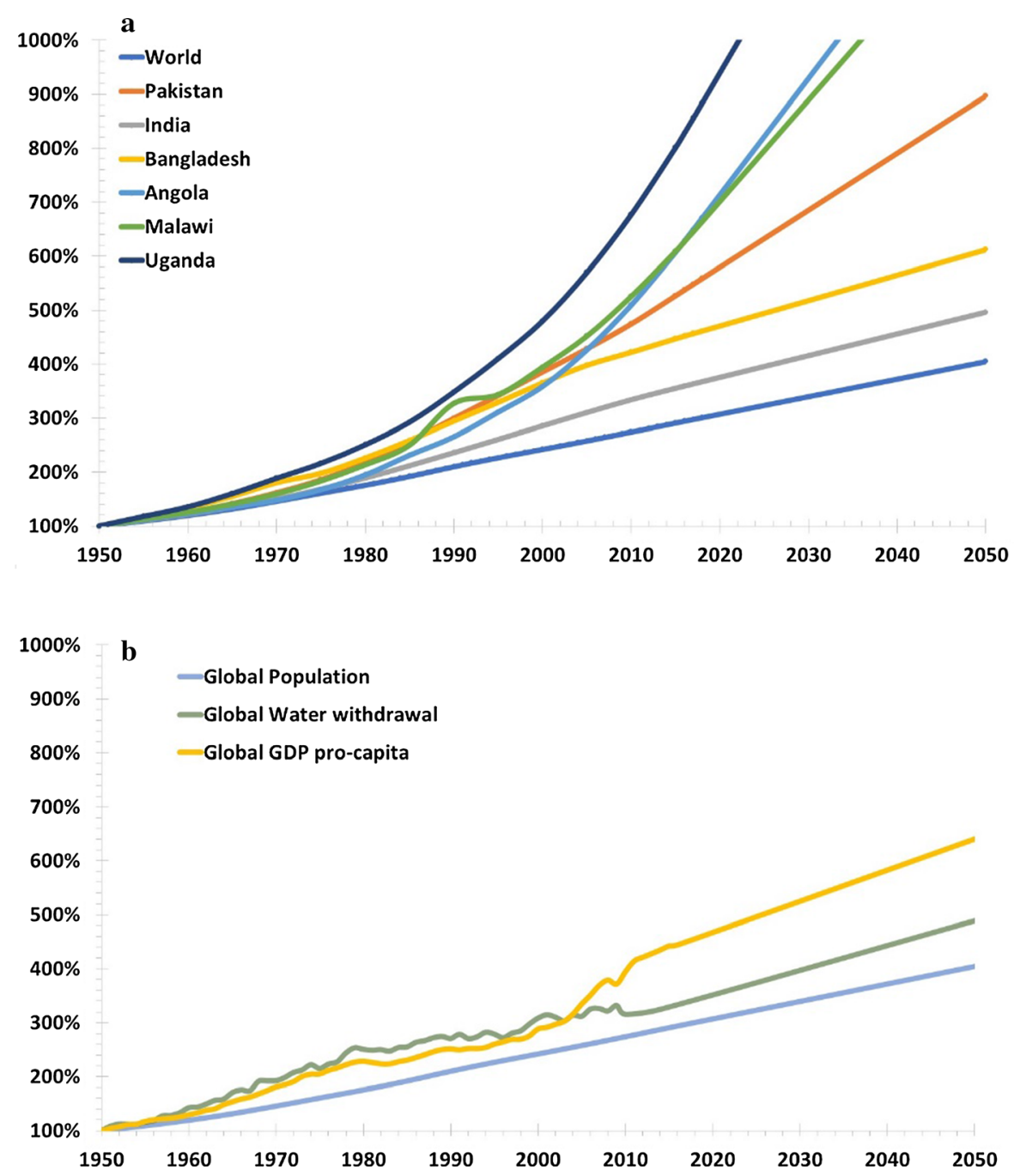

Fig. 3 a Population, global, and selected countries, 1950-2050. b Global GDP per capita, water withdrawals, and population from 1950 to 2050. Images from (Boretti and Rosa 2019). CC-BY

scarce at least 1 month each year by 2050. It is estimated that over 5.7 billion people will suffer from a lack of water of acceptable quality by 2050 .

How these mild or hard scarcities translate in practical aspects of everyday life of people and more importantly impact on their life quality, life expectancy and population growth rate are difficult to be understood. Certainly, conditions in Africa will be much different from the conditions in Europe or North America.

Africa has the fastest-growing population worldwide, despite suffering water scarcity more than every other continent (United Nations Water 2019).

Africa is also very poor.
The predictions of United Nations Water (2019) do not account for the worsening of the water quality by pollution, or the depletion and salinization of aquifers, that were only marginally factored in United Nations Water (2019) or United Nations Water (2018).

\section{Shrinking water resources}

Water withdrawal is not representative of water shortage. The increasing water use is also accompanied by the expanding pollution of the freshwater that is not represented in the diagram in Figs. 3 and 4 (Boretti and Rosa 2019). The available clean water 
a

\section{GDP per capita, 2016}

GDP per capita adjusted for price changes over time (inflation) and price differences between countries - it is measured in international-\$ in 2011 prices.
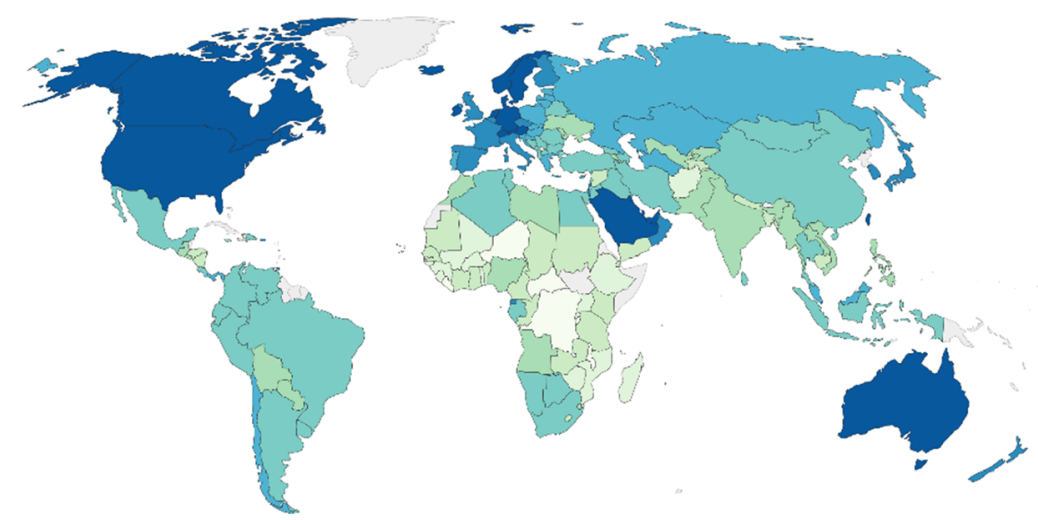
No data $\$ 0 \quad \$ 5,000 \quad \$ 10,000 \quad \$ 20,000 \quad \$ 30,000 \quad \$ 40,000 \quad>\$ 50,000$
Source: Maddison Project Database (2018) OurWorldlnData.org/economic-growth • CC BY Note: These series are adjusted for price differences between countries using multiple benchmark years, and are therefore suitable for cross-country comparisons of income levels at different points in time.

\section{b}

Water withdrawals per capita, 2010

Total water withdrawals from agricultural, industrial and municipal purposes per capita, measured in cubic metres $\left(\mathrm{m}^{3}\right)$ per year.

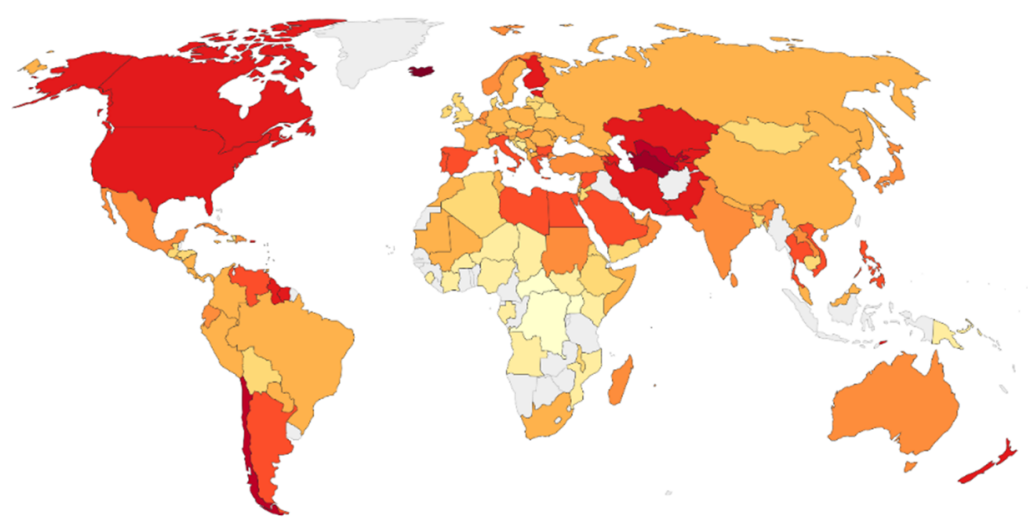

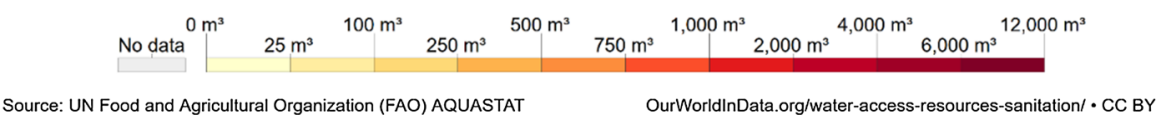

Fig. 4 a GDP per capita. b Water withdrawal per capita. c Population growth rate. d Water stress. Images from https://ourworldindata. org/. CC-BY

reduces and the demand for clean water increases (Boretti and Rosa 2019). Assuming that water pollution is increasing even faster than population, fastgrowing populations in areas where water is already scarce, are likely to experience water crises sooner.
The higher growth rates in the population are in the poorest areas of the world, where expensive, energyintensive remedies such as desalination are impossible to provide (Boretti and Rosa 2019). 


\section{c}

Population growth rate, 2015

Annual rate of population change from 1950, including UN projections to 2100 based on its median scenario. This takes births, deaths and migration into account.
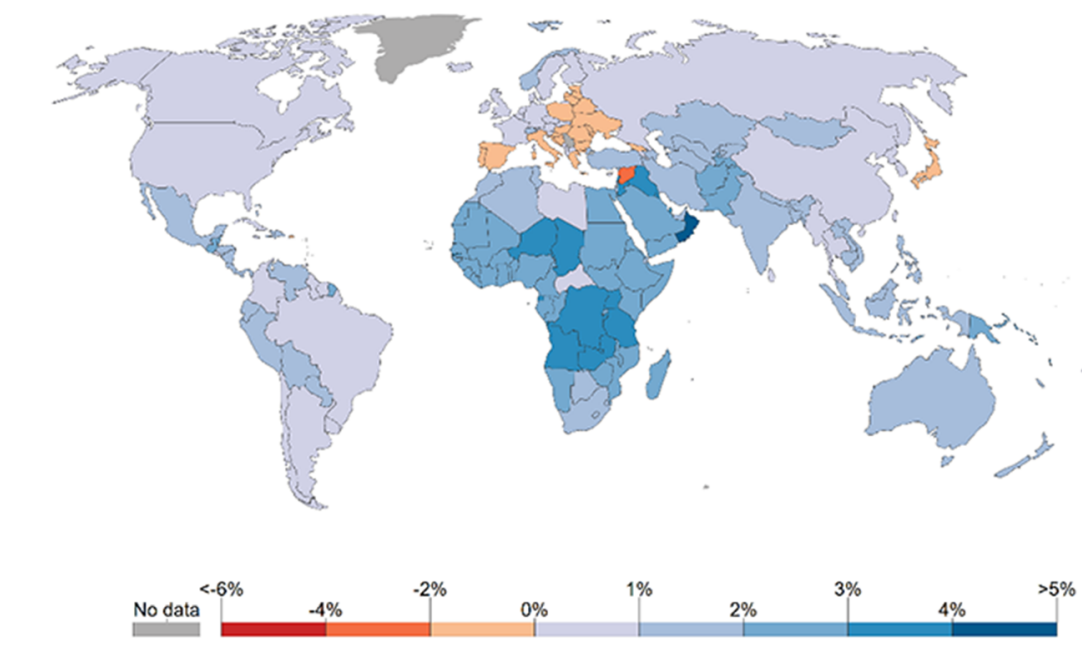

Source: UN Population Division (2017 Revision)

OurWorldlnData.org/world-population.growth/ $\cdot$ CC BY

\section{d}

Freshwater withdrawals as a share of internal resources, 2014

Annual freshwater withdrawals refer to total water withdrawals from agriculture, industry and municipal/domestic uses. Withdrawals can exceed $100 \%$ of total renewable resources where extraction from nonrenewable aquifers or desalination plants is considerable.
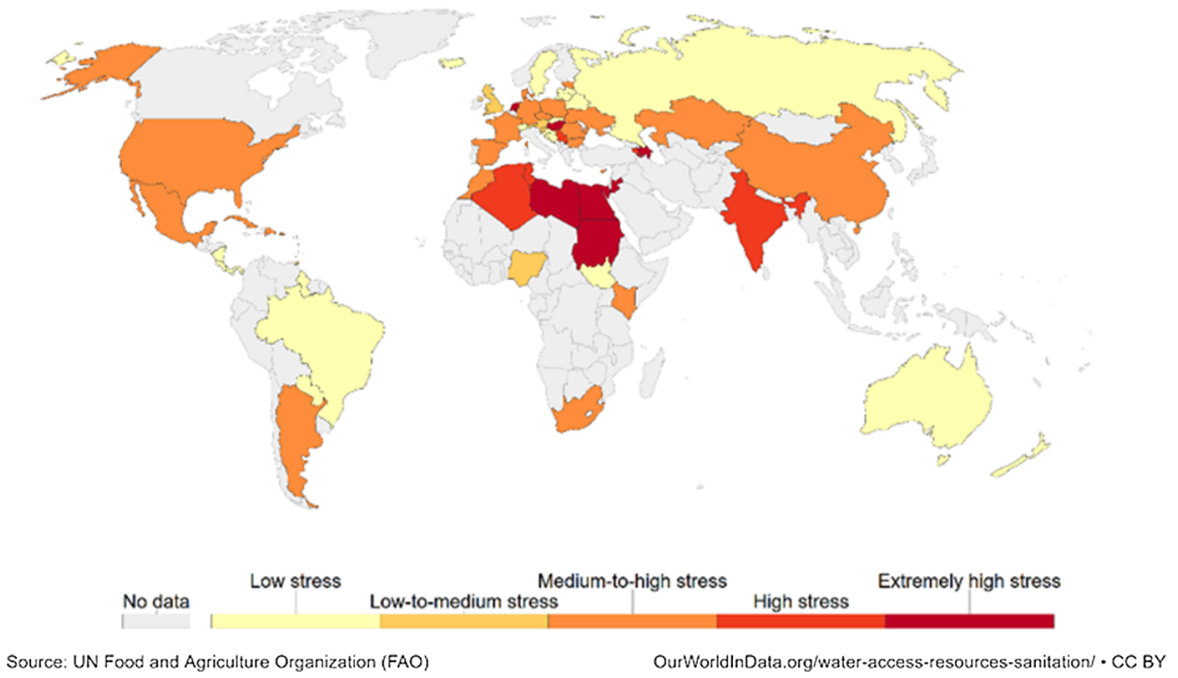

Fig. 4 continued

This means that worsening health conditions and lack of water and food will be dramatic in Africa, and mass migration from Africa towards Europe will increase.

Population growth prompts larger water use. While the rich close to the coast can use desalination, the masses of poor in areas far from the ocean cannot use this technique, and this may exacerbate the local severity of the water crisis.

The number of people that may suffer from clean water scarcity by 2050 will be larger than the estimate in United Nations Water (2019), because the impacts 
of the drivers of water shortage, excessive population, and economic growth, plus the effect of inequality and accessibility, and the role of reduction and pollution of the aquifers, are underestimated in the report.

It is the future of the world economic system, as well as the future of the energy supply, that is particularly worrying, and this was not even mentioned in United Nations Water (2019).

\section{Globalization and water scarcity}

The relatively recent global growth of population, economy, wealth, life quality and life span, has been achieved through dramatic, large use of coal, natural gas, and oil, within a capitalistic system, based on free markets, and independent countries, plus the spectacular technological developments. The opportunity to tackle an impending water issue is dependent on the way economy and energy will progress. Without energetic and economic resources, the water crisis could affect many more people than what is considered in the United Nations Water (2019). A water crisis also affects food production.

Population, economy, energy, water, and food are strongly related to each other, and a domino effect can produce catastrophic results (Boretti and Rosa 2019). Thus, the water crisis is more real than what could be expected, and the difficulties to prevent originates from the political and economic spheres. Same as the solution to the problems of Africa.

Scarcity, in general, is a highly contested concept (Jaffee and Case 2018). Non-existing or exaggerated threats have long been used and abused.

Scoones et al. (2019) talk about the "narratives of scarcity" used to add assets considered underutilized, prompting contestations over rights and qualifications, and delivering new scarcities. The shortage is unforeseen, relevant, social, and, more al, political.

According to Mehta et al. (2019) scarcity is a risky thought that has for quite some time been a totalizing talk in resource politics and financial matters. A new politics of scarcity is related to new arrangements of characters, new political-financial relations and new spatiality, and topography of asset control and savagery.

According to Hildyard (2019) every social issue is, at root, an issue that appears from a shortage. The use of the human right to water versus the neoliberal water arrangement is discussed in Karunananthan (2019). Human rights talk and corporate talks are both planned for legitimizing amassing by dispossession. Human rights can upset the work of the neoliberal state in encouraging procedures of aggregation by dispossession in the competition over freshwater supplies. Schmidt and Matthews (2018) indicates a waterenergy-food-climate nexus quickly growing in the worldwide water administration. Global finance is using the nexus to affect the progress from statearranged advancement models to financialized approaches of water improvement and sustainability relating the water-energy-food-climate to the progress of the global economy.

As globalism necessitates an unbounded economic and demographic growth to proliferate, the limits of growth, previously very well documented in the literature, were recently becoming very limited.

Boulding declared in (1973), testifying to the US Congress, "Anyone who believes in indefinite growth in anything physical, on a physically finite planet, is either mad or an economist" (Boulding 1973). However, this was 2 years after the United States unilaterally terminated convertibility of the US dollar to gold, determining the end of the Bretton Woods system (Steil 2013), which permitted unprecedented stability in the finance system regulating monetary relations among independent states since the end of World War II.

After the end of Bretton Woods, the United States made of the US\$ a free-floating currency. The number of the banking crisis that increased dramatically before the start of Bretton Wood, and was virtually eliminated during Bretton Wood, started to grow again more than ever before (Steil 2013). The sharp increase since the end of Bretton Woods of the world global debt, coupled to the printing of US\$ and EUR without any link to the fundamentals of the United States or the European Union economy, cast doubts about the real strength of the global economy, and more than that the sustainability of this model.

The total global debt (public plus private) reached in 2018 US $\$ 188$ trillion, for a global average debt-toGDP ratio (weighted by each country's GDP) up to $226 \%$ in 2018 (Moreno Badia and Dudine 2019).

Therefore, the limits to growth are being downplayed for an economy that is not even really improving, with population growth appearing more and more unsustainable. The role of overpopulation in 
the depletion of natural resources and reducing the resilience of ecosystems highlighted in many works such (O’Neill et al. 2010; Peacock 2018; Meadows and Meadows 2007; Jackson 2009; Campbell 2012) are now drastically downplayed, with the progress of globalization. A discussion of the limits to population growth, pollution, and economic development, is mostly missing in the latest sustainability debates (Kopnina and Washington 2016). Overpopulation arguments are harshly criticized in the recent literature, often portrayed as "anti-poor", "anti-developing country" and "anti-human".

There are political and economic interferences preventing a full understanding of the real threat to humanity produced by a water crisis, triggered by unbounded, unequal growth of the economy and the population, with questionable economic fundamentals, and subjected to the strong interactions between water, food, energy, and economy.

\section{Technological improvements and water scarcity}

There is to mention also confidence in technological improvements, to reduce the water that is wasted, recycle the water, and produce new freshwater, that opposite to the many negative factors previously outlined is otherwise positive.

Agricultural yields have been dramatically increased in recent years thanks to improved technologies, with food production outpacing the growing demand of a growing population despite the reduced land per capita for cultivation (ourworldindata.org). But can technology do the same to address the imminent water crisis? And can technology succeed in this difficult task, if the energy resources will be reduced rather than expanded, and if the available economic resources will be similarly insufficient?

\section{Covid19 epidemiological models}

The above business-as-usual scenario has been recently complicated by the Covid19 outbreak. Started in Wuhan, China, the coronavirus Covid19 infection is now affecting almost every country and territory around the world (Roser et al. 2020). Despite the epidemic has been placed under relative control in some countries of Asia such as China, South Korea,
Hong Kong, Japan, Singapore, and Taiwan, especially Western Europe and the United States, had an epidemic of more dramatic consequences than those experienced in Asia (Worldometer 2020; Roser et al. 2020). The most part of the world is following the panicking of Western Europe and the United States for what concerns containment measures.

The Covid19 death rate for the Hubei Province computed as total deaths versus total population is $5.35 \times 10^{-5}$ (Worldometer 2020; Roser et al. 2020). The Covid19 death rate for China similarly computed is $2.27 \times 10^{-6}$ (Worldometer 2020; Roser et al. 2020). New York City had a fatality rate of 2500 every million people or $2.5 \times 10^{-3}$. There is a factor of 1000 that should prompt questions unfortunately nobody asks.

The United States Center for Disease and Control (Fink 2020) estimated for Covid19 between 160 and 214 million people could be infected only in the United States, and as many as up to 1.7 million people could die. 1.7 million over 330 million people is $5.15 \times 10^{-3}$.

According to the predictions of last March trusted by the government of the United Kingdom and never revised (Adam 2020; Ferguson et al. 2020), there should have been more than 500,000 deaths in the UK, and 2.2 million deaths in the US, "if the government take no action".

Ferguson et al. (2020) predicted 4 months of the outbreak in the United Kingdom, with a peak of mortality of 21 every 100,000 , or 21 per million. Nothing similar happened (Boretti 2020a and Fig. 1), but the world approach to Covid19 has not changed. While previously the new social-distancing measures would have been temporary, then these measures started to be suggested to last longer (Nuki 2020), to be held in place until a vaccine or treatment will be found, perhaps a year or more, as if they were lifted early, many more would likely die.

Figure 5 presents in (a) the computations of the death rate from Adam (2020) and Ferguson et al. (2020) for the United Kingdom and the United States. In (b) and (c) are the measurements of Covid19 mortalities (b) per million people from countries in Europe, the United States, and Canada, plus South Korea, Australia, and Saudi Arabia, and in (c) the total from China. The population of China is 1.5 billion people. The fatality rates in Fig. 5 are updated to April, 2020. The latest fatality rates are in Fig. 1. After 


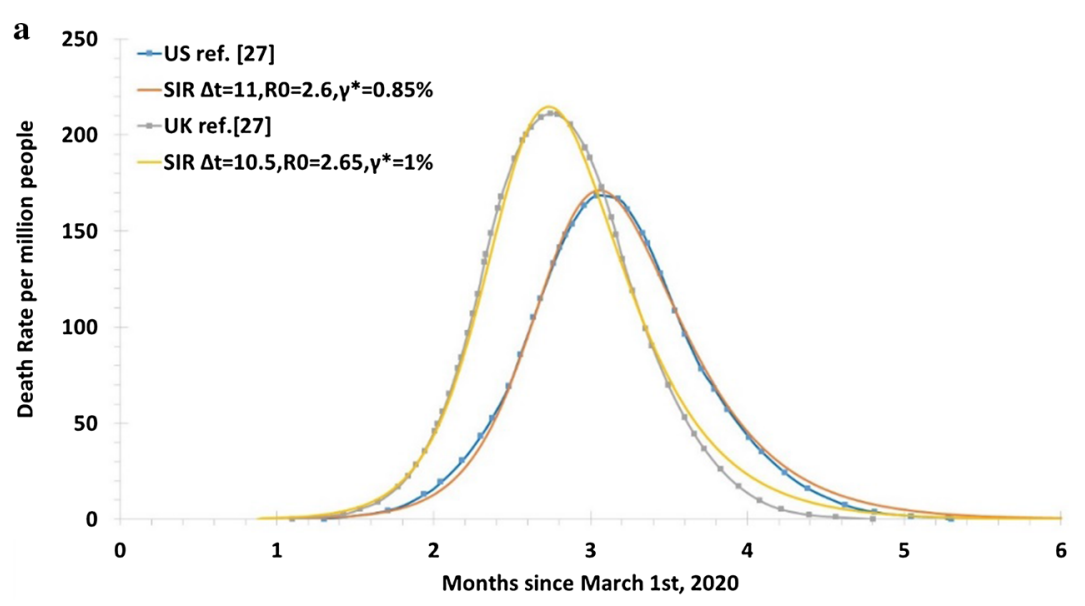

b

Daily confirmed COVID-19 deaths per million

Shown is the 7-day rolling average. Limited testing and challenges in the attribution of the cause of death means that the number of confirmed deaths may not be an accurate count of the true number of deaths from COVID- 19 .

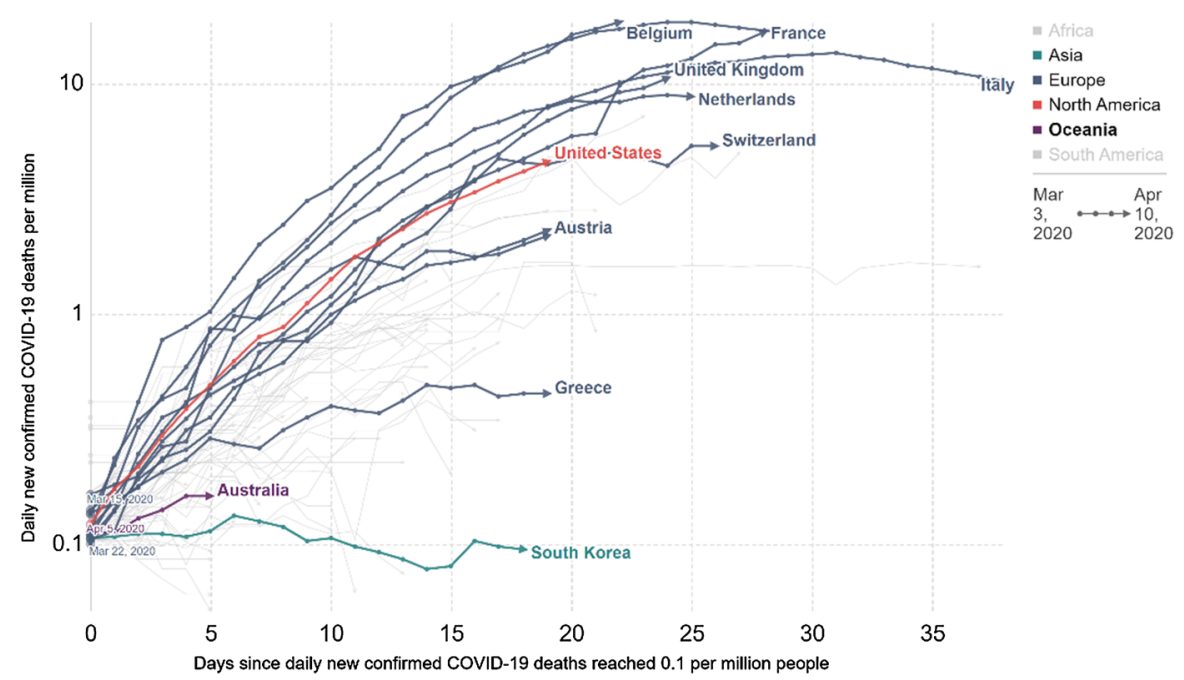

Source: European CDC - Situation Update Worldwide - Last updated 10th April, 12:00 (London time) OurWorldlnData.org/coronavirus $\cdot$ CC BY

Fig. 5 a Computations of the death rate from (Adam 2020) and (Ferguson et al. 2020) for the UK and the US. b and c Measurements of Covid19 mortalities b per capita from countries in Europe, the US, and Canada, plus South Korea,

a few weeks the predictions by Ferguson et al. (2020) were already openly wrong but nothing changed.

The death rate from Adam (2020) and Ferguson et al. (2020) is in a proportion of the population. Ferguson et al. (2020) use deaths per 100,000 as a parameter. The simulations of Ferguson et al. (2020), reported in Adam (2020), that have inspired the world lockdown, were very little more than a SIR model (Kermack and McKendrick 1927), a simulation of three parameters subjectively assumed, as it is shown
Australia and Saudi Arabia, c total from China. The population of China is 1.5 billion people. The data of China may be wrong. Images reproduced from https://ourworldindata.org/ coronavirus-data. CC BY

in (a). As explained in Boretti (2020a) the SIR model is based on the number of (S) susceptible, (I) infected, and $(\mathrm{R})$ recovered or dead (Kermack and McKendrick 1927). Then, it is simply:

$$
\begin{aligned}
& \frac{d S}{d t}=-\beta \cdot S \cdot I \\
& \frac{d I}{d t}=\beta \cdot S \cdot I-\gamma \cdot I
\end{aligned}
$$




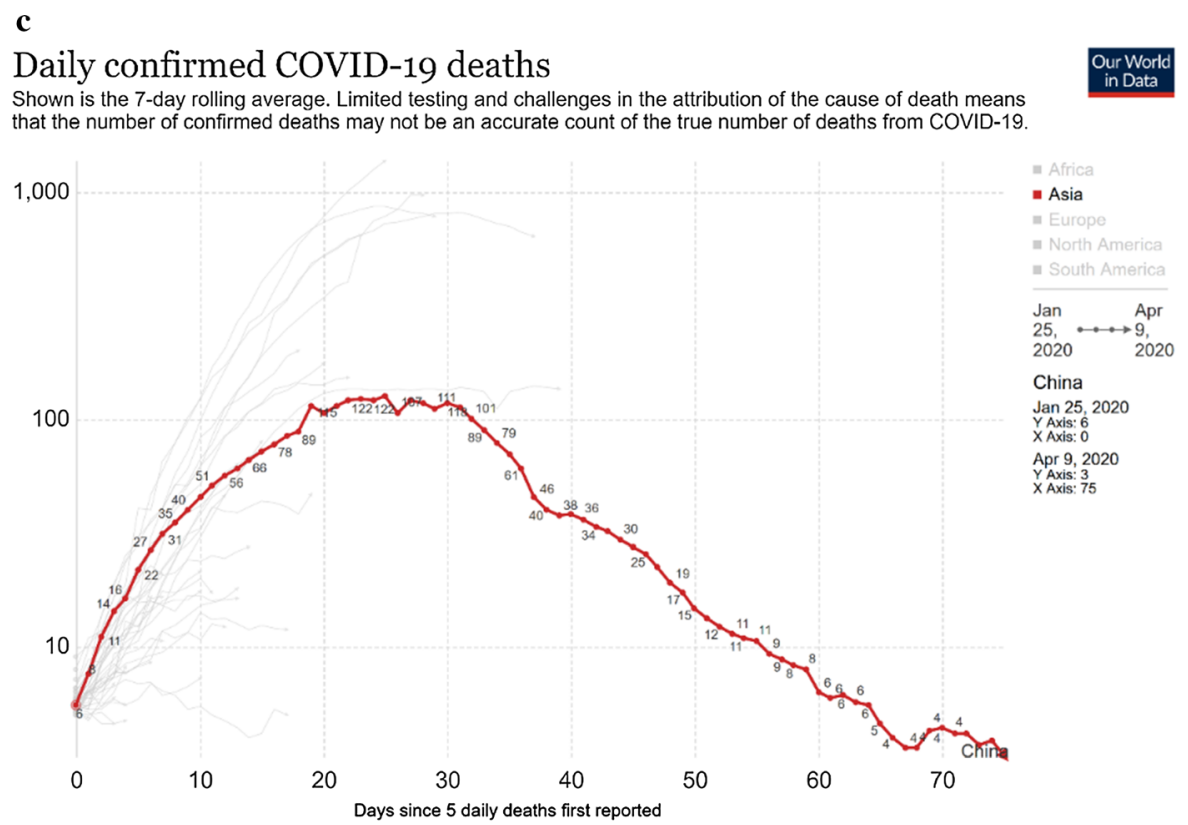

Source: European CDC - Situation Update Worldwide - Last updated 9th April, 11:45 (London time) OurWorldlnData.org/coronavirus • CC BY

Fig. 5 continued

$\frac{d R}{d t}=\gamma \cdot I$

where $t$ is the time, typically in days, $\beta$ is the infection rate and $\gamma$ is the rate of recovery. The average number of days to recover (or die) from infection is

$\Delta t=\left(\frac{1}{\gamma}\right)$

and the basic reproduction number is:

$R_{0}=\left(\frac{\beta}{\gamma}\right)$

The death rate can be taken equal to the time rate of change of the number of closed cased $\mathrm{R}$

$\frac{d M}{d t}=\gamma^{*} \frac{d R}{d t}=\gamma^{*} \cdot \gamma \cdot I$

where $\gamma^{*}$ is the percentage of deaths in closed cases.

Adam (2020) and Ferguson et al. (2020) subjectively estimate that $0.9 \%$ of the infected would die and that $R_{0}$ is about 2.6. These numbers are overrated. Many of those who may have been infected that are mild or asymptomatic were not considered, and true infectivity and lethality were exaggerated (see Fig. 1). Opposite to the simulations, the peak mortalities have been less than 0.1 per million in China, and about 10 per million in Europe, despite there the death statistic may have been overrated. The simulations Adam (2020) and Ferguson et al. (2020) suggested 210 per million in the United Kingdom. There is more than one order of magnitude difference. Similarly, longer was the predicted length of the outbreak in the United Kingdom, almost double of what was then measured (Fig. 1).

Even if similar models have been proposed to compute the Covid19 outbreak in Africa, we do not believe it is reasonable. It is unclear which mortality will be experienced in developing countries such as Africa for Covid19, where the causes of premature death are many, and lack of food and clean water is already a reality, and similarly, worrying is the lack of a health system. But it seems appropriate not to use the model of Ferguson et al. (2020) to estimate fatalities in Africa.

If we take for realistic the number of Adam (2020) and Ferguson et al. (2020) where $65-75 \%$ of the population of the United States or the United Kingdom get infected, and 0.65 and $0.75 \%$ of the population die, Africa, will be destroyed by the virus. But as shown in Fig. 1, this has not happened so far, and the most affected African country is the ex-British-colony that 
was supposed to enjoy the best health system and infrastructure of the continent.

The concept of "herd immunity" pictured as impossible to be applied to Covid19, with containment through distancing and borders restriction the approach followed by almost every country of the world (Boretti 2020c) is however working in Sweden. Prolonged distancing and borders restriction translates into further damages to the economy while preventing "herd immunity" and posing risks of second waves of Covid19 infection (Boretti 2020c).

The slowdown of the economy will translate in much harsher conditions in the developing world, with even more reasons to migrate and even fewer opportunities, with the risk to make the water and food and health crisis, especially in Africa extremely severe.

Some of the countries such as South Korea or The Netherlands, do not adopt complete lockdowns, but still distancing and border control is much harsher than before (Boretti 2020c). The Netherland has fewer deaths than the neighboring Belgium that has complete lockdown (Boretti 2020c). The United Kingdom had a peak death rate below 15 over a million, versus the predicted 210, and a length of the outbreak shorter than 5 months (Boretti 2020b). Sweden did much better without any lockdown.

\section{Covid19 infectivity and fatality}

Bendavid et al. (2020) has indicated that the number of coronavirus infections maybe 50-80 times higher than the official count because of the asymptomatic and mild cases undetected. This was the first large-scale community-based prevalence study completed during a rapidly changing pandemic and with newly available test kits. This work suggested the infection fatality rate is between 0.12 and $0.2 \%$. As the fatality rate usually reduces with the progress of the infection, the lower estimate is the more appropriate. This is slightly more than the fatality rate estimated for the common flu for all ages, which is $0.096 \%$ (US CDC 2020), but much less than that $0.9 \%$ of the models such as Adam (2020) and Ferguson et al. (2020).

Similar values of mortality rates are proposed by the Oxford Covid19 evidence center (Oke and Heneghan 2020). Their infected fatality rate (IFR) for Covid19 is somewhere between 0.1 and $0.36 \%$ also accounting for the number of undetected asymptomatic or mild cases. According to (Day 2020), $50-80 \%$ of the test-positive remain symptomfree. According to niid.go.jp (2020), even among the $70-79$ years old, about $60 \%$ remain symptom-free. In the general healthy population, people who do not get infected even if challenged by the Covid19 virus are the majority.

A fatality of $0.15 \%$ has also been recently computed by Boretti (2020e) for Saudi Arabia.

In the case of the French aircraft carrier Charles de Gaulle (Sinkins 2020), a difficult place where to enforce confinement and distancing, about 1081 of a total of about 2000 tested positive. Almost one half of the tested positive were symptoms free and the other half had only mild symptoms. Only 24 required hospitalizations, with only 1 requiring intensive care 10 days after the outbreak. In the end, everybody recovered for a total fatality of zero (Boretti 2020d).

From what may be inferred in the mortality rate (the infection rate is not realistic), Figs. 1 and 5, peaks were reached in Western Europe usually after less than 30 days since a 0.1 per million mortality rate was achieved, no matter more or less restrictive distancing. Belgium has the world's largest (as a country of more than 1 million people) mortality rate at 28.8 per million despite the stringent restriction measures. The length of the outbreak is likely less than what proposed in the models such as Ferguson et al. (2020) as well as the peak mortality rate. Thus, there is growing evidence that most of the individuals do not get infected or are asymptomatic or are mild cases, and hospitalization is mostly needed only for risk categories of elderly people or people with comorbidities, who make up almost the totality of the deaths (Istituto Superiore di Sanità 2020; Comas-Herrera et al. 2020; Swiss Propaganda Research 2020).

Age and risk profile of deaths corresponds to the normal mortality profile.

The actual numbers do not justify the panic for Covid19. Measures should be tailored to protect the risk groups, not to prevent every movement of healthy peoples. Many, such as off-guardian.org (2020a, b), consider the distancing measures taken to be counterproductive and recommend a rapid natural immunization of the general population while protecting the risk groups. 


\section{Herd immunity and vaccines}

Nobody knows how things will then progress. One problem is the real threat from the virus, another is the way governance and economy will develop. Most of the countries in Western Europe and North America have moved to lockdown measures that are dramatically damaging the economies of these countries leading to the local and global recession. Lockdown until further notice as the only way to cope with Covid19 is also being spread to countries, such as Africa, where social distancing is a difficult concept to be applied, and other health issues, plus the unavailability of water and food for the many poor should have been considered carefully.

Herd immunity through a significant percentage of people who have been infected and then recovered has been briefly considered at the start of this year in the United Kingdom and then dropped for unclear reasons except than in countries such as Sweden that certainly did not worse than the United Kingdom in containing the Covid19 fatalities (Boretti 2020c). However, it may work in Africa. Herd immunity through mass vaccination is more unlikely to work than herd immunity.

The time frame to properly develop a vaccine is long, and the result is uncertain. Near past experiences for SARS and MERS, close relatives of Covid19, have been unsuccessful. The start of human trials of Covid19 vaccines without proper safety studies in animal risks to produce more downfalls than benefits. Animals vaccinated using spike protein-based vaccines against SARS and MERS had worse outcomes when challenged with the viruses. Research into SARS and MERS vaccines were not abandoned because funding was withdrawn for no reason. The SARS outbreak ended before the vaccines were ready. After 5 years from the SARS outbreak, in 2008 (Enjuanes et al. 2008), despite the vaccine candidates for this specific coronavirus were more successful than for other coronaviruses, efficacy and safety evaluation in humans were still to be started (Enjuanes et al. 2008). There are presently two vaccines in use against coronaviruses, but not for humans. They are veterinary vaccines and do not work very well. As optimistically reported in (Roper and Rehm 2009), "vaccinated animals still display significant disease upon challenge". Similarly, the MERS coronavirus outbreak is ongoing since 2012. As stated by (WHO 2019a), no vaccine (or specific treatment) for MERS is currently available.

Finally, the Covid19 vaccines under consideration are not conventional vaccines but mRNA (messenger RNA) vaccines. Despite very promising (Pardi et al. 2018), they have been proposed for many applications, from viral infections to cancer to allergy, but no product has passed so far through human trials for safety and efficacy.

Importantly, according to the WHO (2020a) “There is currently no evidence that people who have recovered from COVID-19 and have antibodies are protected from a second infection". They attribute same value to published studies such as Wölfel et al. (2020) or To et al. (2020) or one preprint study still not accepted (Wu et al. 2020) to claim "Most of these studies show that people who have recovered from infection have antibodies to the virus" however "some of these people have very low levels of neutralizing antibodies in their blood, suggesting that cellular immunity may also be critical for recovery". While regarding herd immunity the WHO says "no study has evaluated whether the presence of antibodies to SARSCoV-2 confers immunity to subsequent infection by this virus in humans" (WHO 2020a) it is granted by default that vaccine-induced-SARS-CoV-2 antibody is protective against SARS-CoV-2 (WHO 2020b).

\section{Sustainability of the Covid19 containment measures}

The mandatory lockdown for every possible person, even extremely healthy people with minimal risk factors, is going to have serious, yet-to-be-determined consequences. Mandated behaviors such as travel bans, hand washing, closures of public events and gatherings, and social distancing are in principle designed to "flatten" the virus growth curve and give the healthcare system time to cope. But how long can these prohibitions be enforced? and are these precautions effective? And how these measures apply within the reality of Africa? While the epidemiological efficacy is being questioned, there is no doubt these measures affect the economy.

The average human body normally contains trillions of cells, trillions of bacteria, and trillions of viruses, normally living together. Aged individuals have damaged immune systems because of a lack of 
micronutrients that strengthen their defense systems. Exposure to toxic substances and an unhealthy way of life also make a difference. Younger people with a damaged immune system are also at risk. However, our economy cannot survive on minimal activity forever. There is no doubt the virus will spread, but whatever its course, the experts who recommended the quarantine to be extended indefinitely, have said nothing about plans to restore living and working conditions, when the infection ceases to be active. It is completely unclear which indicators in the virus data will produce a change of policy. It is worth considering if the measures undertaken to prevent the spread of the virus are sustainable, if these measure are effective, and if they will cause more damage than create any benefit if maintained for many months.

What measures are being planned to prevent a social catastrophe, a devastated economy, a ravaged quality of life, and stunted population growth, plus water and food and other health crises in developing countries such as Africa? The destruction of the present economic system will inflict an even worse outcome than if we were to maintain a nearly usual behavior during this health crisis, with only reasonable precautions.

While unnecessary gatherings may certainly be avoided, there is no doubt that many activities cannot simply be shut down until further notice because of unknown or uncertain developments caused by a virus. Whereas the consequences to our lives if society is closed down for the foreseeable future, are known and are certain.

\section{Economic damage of Covid19 containment measures}

The outbreak and the response to the outbreak damage economies and limit movements. They also affect the ability of many to make a living and procure food and water. This is difficult to be quantified or put into the context of the GDP proposed earlier in this paper because predictions are continually evolving. According United Nations Department of Economic and Social Affairs (2020), as per April 1, 2020, the global economy could shrink by almost one percent this year due to the Covid19 pandemic, but world output could contract further if imposed restrictions on economic activities extend to the third quarter of the year and if fiscal responses fail to support income and consumer spending. As per April 6, 2020, (IMF 2020) reported that as a result of the pandemic, the global economy is projected to contract sharply by $3 \%$ in 2020 , much worse than during the 2008-09 financial crisis.

All these predictions were made before Covid19 become a global pandemic, and before the implementation of widespread restrictions on social contact and borders closure to stop the spread of the virus. It is this dynamic of travel restrictions and consumer spending that has economists contemplating whether the Covid19 pandemic could lead to a global recession on the scale of the Great Depression (Duffin 2020).

The effect of the previous epidemic such as SARS in Asia, or Ebola in West Africa, is not an indication for the costs of Covid19, being the problem in these outbreaks much more local. This time the issue is global, and this time it is also affecting Europe and the US, previously practically immune.

Figure 6 presents in (a) the latest GDP per capita of China, the United States, and selected other countries. There is no sign of any sharp decline associated with the 2003 SARS and 2014 Ebola outbreaks. SARS first emerged in China's Guangdong province before spreading to other countries. The virus infected about 8000 people, claimed almost 800 lives worldwide and only reduced by $0.5-1 \%$ of China's growth in 2003 , according to various estimates (Feuer 2020). The effect on the global economy was minimal. Regarding Ebola, (US CDC 2016), as of February 28, 2016, there were 28,639 suspected, probable, and confirmed cases of Ebola and 11,316 deaths from Ebola during the 2014 epidemic in West Africa. In comparison, there were 2427 reported cases and 1597 deaths in all other known cases and outbreaks of Ebola combined. According to the 2014 projections, an estimated \$2.2 billion was lost in 2015 in the gross domestic product (GDP) of the three countries most affected. While this may certainly have been relevant to the economies of the three countries, it is irrelevant to the global GDP.

Thus, it is impossible to understand how much the GDP will shrink globally because of Covid19, how movements of people will be reduced because of Covid19, and how this will impact clean water availability in Africa through the economic mechanism.

So far, the economy and population have grown together, and because of economic growth, it has been possible to feed more people through technological 


\section{a}
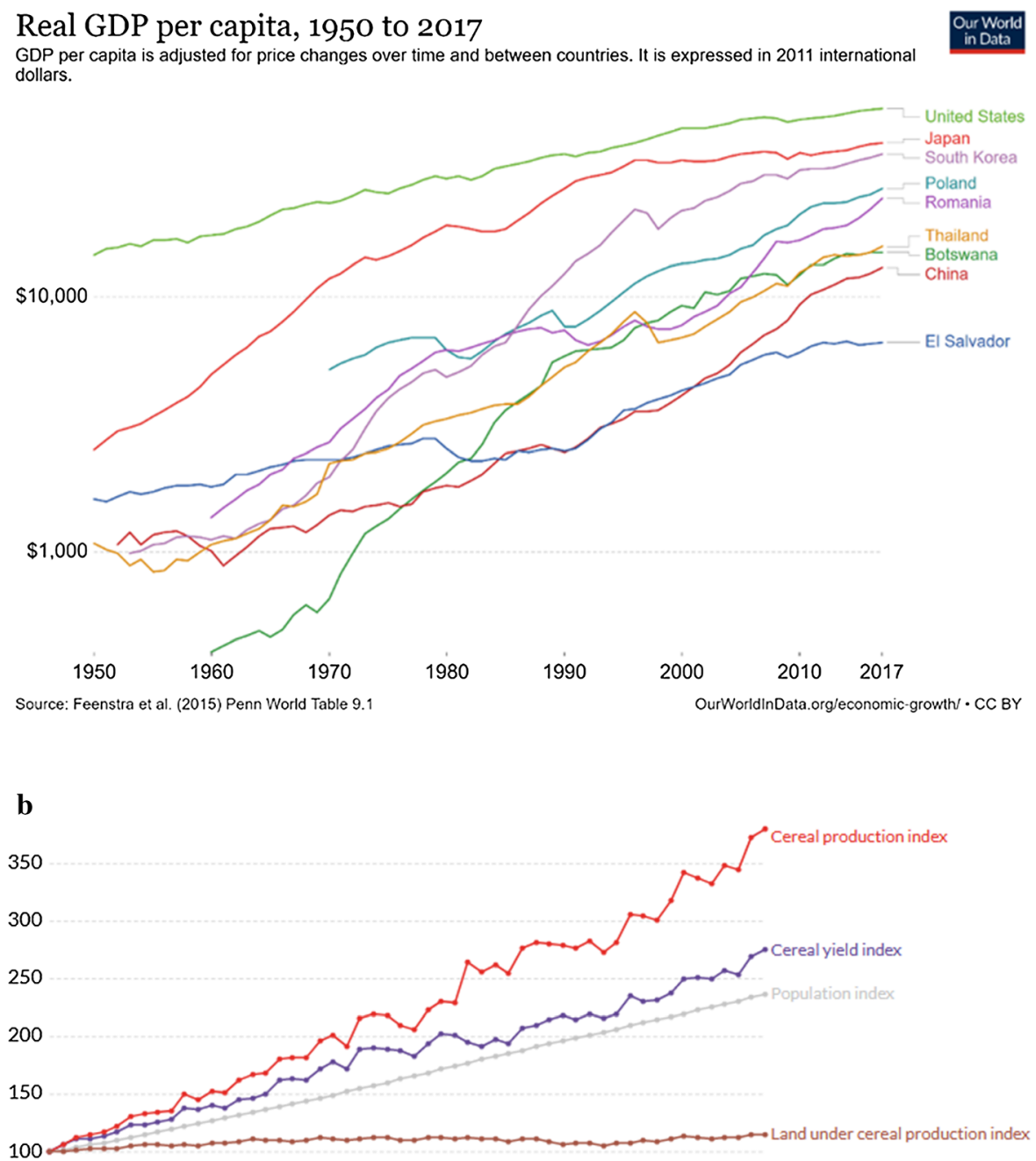

50

$$
0
$$

$\begin{array}{llllll}0 & 1961 & 1970 & 1980 & 1990 & 2000\end{array}$

Fig. 6 a The latest GDP per capita of China, US, and selected other countries. There is no sign of any sharp decline associated with the SARS and Ebola outbreaks. Image reproduced from https://ourworldindata.org/economic-growth. b Index of cereal

improvements. As shown in Fig. 6b, over the last 50 years, the global population has more than doubled. The land available per person to grow food has reduced. Feeding of the rapidly growing population with shrinking land resources has been made possible mostly by increasing the yield output with improvements of water use and farming practices, the use of higher-yielding crops, fertilizers, pesticides, and herbicides (http://ourworldindata.org). production, yield and land use, 1961-2014, World, https:// ourworldindata.org/yields-vs-land-use-how-has-the-worldproduced-enough-food-for-a-growing-population

Feeding of a rapidly growing population in Africa with a shrinking local and global economy and borders restrictions is impossible.

According to World Bank (2020), due to Covid19, Sub-Saharan Africa will experience the first economic crisis in the last 25 years. Forecast is to fall from $+2.4 \%$ in 2019 to -2.1 to $-5.1 \%$ in 2020 . They mention as drivers trade and value chain disruption, reduced foreign financing from remittances, tourism, 
foreign direct investment, foreign aid, capital flight; direct impacts on health systems, disruptions from containment measures, and disruption from the public response. The crisis has the potential to spark a food security crisis, with agricultural production contracting $2.6-7 \%$ if there are trade blockages. Food imports would decline substantially by $13-25 \%$ due to higher transaction costs and reduced domestic demand.

\section{Climate change and water scarcity}

Climate change is also one of the drivers of the water crisis (United Nations Water 2018, 2019). Climate change is altering the global water cycle and this is one of the reasons scarcity will increase by 2050 (United Nations Water 2018, 2019). However, the same as Covid19, the way to address climate change is anything but clear.

The anthropogenic $\mathrm{CO}_{2}$ emission is one of the drivers of the atmospheric $\mathrm{CO}_{2}$ concentration, and not only a direct, but also an indirect driver (Boretti 2020a). The net balance of atmospheric $\mathrm{CO}_{2}$ is the result of land emission, ocean emission, and anthropogenic emissions, plus land sequestration, and ocean sequestration (IPCC 2014). The direct anthropogenic $\mathrm{CO}_{2}$ emission to the atmospheric $\mathrm{CO}_{2}$ is relatively small (Salby 2012). The ocean surface temperature is the primary driver of the atmospheric $\mathrm{CO}_{2}$ concentration. The anthropogenic $\mathrm{CO}_{2}$ emission is directly responsible for the increased atmospheric $\mathrm{CO}_{2}$ concentration, and indirectly through the warming temperature.

There are however other anthropogenic and natural forcings. Warming may also result from other causes, like changes in solar activity (Solanki et al. 2004; Usoskin et al. 2003; Solanki and Krivova 2003), or changes in the land use (Pielke et al. 2009, 2016; Pielke 2013) or the effect of other pollutants.

Even only focusing on the atmospheric $\mathrm{CO}_{2}$ concentration, if the anthropogenic $\mathrm{CO}_{2}$ emission reduces, the other harmful anthropogenic drivers of global warming remain as changes in land use, and other pollutants also disrupt the natural balances. The excess $\mathrm{CO}_{2}$ concentration will continue to affect the climate for a very long time (Frölicher et al. 2014; Knutti and Rogelj 2015). As shown in Boretti (2020a), the drastic reduction in fossil fuel consumption cause Covid19 restrictions has not produced any change in the trend of atmospheric $\mathrm{CO}_{2}$ measured in Mauna Loa over this year. This means that climate change by 2050 will be marginally affected by the transition to renewable energy no matter how fast this could be.

As discussed in "Planets of humans" (www. youtube.com/watch? $\mathrm{v}=\mathrm{Zk} 11 \mathrm{vI}-7 \mathrm{czE}$ ), climate change is not only due to the combustion of fossil fuels, and humans are destroying their planet following many different mechanisms, with some of the remedies worse than the sickness.

As discussed in Boretti et al. (2020), replacement of conventional power plants with renewable energy is expensive, and at least in some cases, such as Saudi Arabia, not providing clear advantages, also from the point of view of the environment. A combined-cycle gas turbine plant such as the 2014 Qurayyah power station in Abqaiq, Eastern Province, Saudi Arabia, of 4000 MW nominal power, had a cost of 2.85 billion US\$. It burns natural gas and oil, with a fuel energy conversion efficiency of $52 \%$ (http://Wikipeen. wikipedia.org/wiki/Qurayyah_IPP). The $4000 \mathrm{MW}$ are always available when needed and the load is decided by the operator. The lifespan of gas-fired power plants is 40 years. A contemporary solar photovoltaic plant, Topaz (http://en.wikipedia.org/wiki/ Topaz_Solar_Farm), in San Luis Obispo County, California, United States, had a cost of 2.5 billion US\$ for $550 \mathrm{MW}$ nominal power. While it does not burn any fuel, it only produces energy during daylight, depending on the availability of the resource. The capacity factor is the ratio of actual generating power to nominal generating power, which is $26.6 \%$. The load is controlled by the variable solar energy source. Fossil fuel energy, and natural resources for the raw materials, are however needed to build the solar PV plant. The life span is not expected to exceed 20 years. The site area is $19 \mathrm{~km}^{2}$. Without energy storage by batteries, even 32 plants such as Topaz do not work the same as Qurayyah. Thus, battery energy storage is needed. The world's largest battery, the 2017 Hornsdale Power Reserve in Jamestown, South Australia, Australia had a cost of $\$ 90$ million for only $100 \mathrm{MW}$ of nominal power, and $140 \mathrm{MWh}$ nominal energy (http://en.wikipedia.org/wiki/Hornsdale_Power_

Reserve). This battery is never charged or discharged at the nominal power and only discharged at a small fraction of the nominal storable energy. The lifespan is unknown. To store $4000 \mathrm{MW}$ for $12 \mathrm{~h}$ (length of day and night is $12 \mathrm{~h}$ on average), there is a need of at least 
343 batteries same of Hornsdale, with this requirement that may dramatically increase if we only charge and discharge the battery at a fraction of the nominal capacity to improve the life span. Fossil fuel energy, and natural resources for the raw materials, are needed again to build the battery energy storage plant. A battery is not expected to last 40 years, especially in the harsh environment of Saudi Arabia, that is also weighting negatively on the efficiency.

Factoring the likely reduced life span of the PV and battery energy storage facilities versus the combined cycle gas turbine plant, production of the same energy with renewables is even worse than with fossil fuels. The 64 solar PV plants such as Topaz, plus the $686 \mathrm{Li}$ Ion batteries such as Hornsdale, that are needed to replace the already existing Qurayyah, do not seem a real advantage for the economy and the environment (Boretti et al. 2020).

\section{Water crisis without Covid19}

With business-as-usual (without Covid19) the number of people that would have suffer from clean water scarcity by 2050 was larger than the estimate in United Nations Water (2019), as the impacts of the drivers of water shortage, excessive population, and economic growth, plus the effect of inequality and accessibility, and the role of reduction and pollution of the aquifers, was there underestimated. This scarcity was expected to be more severe because of the interactions between water, food, energy and economy, and population, with a likely domino effect triggered by one scarcity to the other, in an unstable system (Boretti and Rosa 2019). Governance crises could have also contributed to worsening conditions (Boretti and Rosa 2019).

By 2050, most places are expected to become short of water before they become short of food. Water scarcity is expected to be much more severe at the regional level, especially where there is already scarcity, and the population is growing more, prompting even larger migrations than those already occurring. Africa is the continent where water scarcity is expected before. There is a clear need to manage demography and economy and limit pollution, while better managing and preserving the resources. However, political and economic burdens prevent concrete action.
The unregulated growth of the economy and the population of before Covid19 was expected to continue until the first scarcity or other environmental issues could have badly collide with, then likely translating in the decline of the economy first, and then the population.

(United Nations Water 2019) was a step forward in awareness of water problems but it did not propose any remedies. While United Nations Water (2018) was promoting nature-inspired solutions such as dry toilets, an utterly trivial issue in the imminent world water scarcity, United Nations Water (2019) was marginally better, promoting community-based action to address the root causes of leaving people behind concerning water and sanitation. But vague political slogans do nothing to make the world better. Action is needed on the drivers of water scarcity. Without it, the water crisis is inevitable. Technological changes may certainly help, as it has been often the case in recent human history, but this also requires economic and energetic support, that is difficult to be forecasted.

\section{Conclusion}

With business modified because of Covid19, a water crisis especially in Africa may occur much earlier. Reduced availability of energy, similar to an economic downturn, global and local recession, crisis of global governance, restrictions, in the context of a growing population and growing demand for food and water, will have a drastic impact on global life quality, life expectancy, and net growth rate, and Africa will be the continent to pay most.

The drivers of the water-food-energy nexus are politics, economy, and demography, and they are all strongly related to each other, with one negative factor potentially damaging every other aspect in a world of growing instability.

The Covid19 infection has dramatically changed the time frame of an imminent water (and food and health) crisis for Africa. Because of the prolonged lockdown measures and the damage to the economy, plus the lack of any attention to other priorities such as assuring that water and food are available to people in many parts of the world, it is predictable that a sharp decline of living conditions will occur in many developing countries, and especially in Africa, with 
more reasons and even fewer opportunities to migrate, and less local and foreign help to mitigate.

Covid19 does not affect clean water access in Africa only through the economic mechanism, despite this is the dominant factor. Covid-19 affects water access in many other ways. For example, physical distancing and curfews mean that people cannot leave their house to access food and water, and also the means to purchase food and water. Many poor people commonly do not even have piped utility water.

Depending on how the Covid19 pandemic will evolve, a water crisis will occur sooner or later and will affect Africa before every other continent. Everything will depend on the way the Covid19 pandemic, that is primarily a political issue, will evolve. Poverty will dramatically increase because Covid19.

Covid19 is already driving sub-Saharan Africa toward the first recession in 25 years and this will further add to restrictions limiting the capacity of individuals to seek for water and food, reduced foreign help and local expenditure to help with water scarcity and other issues, and will make the debt of these countries worse than ever.

The issues of Africa, not limited to food and water and health, and Covid19, will only be solved through elimination of poverty and self-determination, GDP growth, and more general growth of know-how, transparency, democracy, and improvements of every other more general societal criterion, within a stable population. Only in this case, there is the opportunity to address environmental and societal issues and solve the water crisis driven by poverty and uncontrolled population growth. With population growth, plus Covid19 economic recession, limited migration, and no international help, the water crisis in Africa will be major problem.

The growing influence of corporations and investment funds and banks of the rich countries on global governance is going to further expand through Covid19. The relationship between the International Monetary Fund and the countries of Africa are examples of a cure that make the patient worse rather than better. From world debt to climate change to Covid19 to the water crisis, there is the impression that things are getting worse rather than better, with conflict of interest in global governance being the open secret that nobody speaks of.
Acknowledgements The author wishes to thank Thomas Connolly for the comments and suggestions provided.

Authors' contributions The author collected the data and wrote the manuscript.

Funding This research received no funding.

\section{Compliance with ethical standards}

Conflicts of interest The author declares no conflict of interest.

Human and animal rights Compliance with standards of research involving animals or humans as subjects is not needed for this work.

\section{References}

Adam, D. (2020). Special report: The simulations driving the world's response to COVID-19 how epidemiologists rushed to model the coronavirus pandemic. Nature, 580, 316-318.

Amuakwa-Mensah, F., Klege, R. A., Adom, P. K., \& Köhlin, G. (2020). COVID-19 and handwashing. Retrieved July 15, 2020, from https://staging.efdinitiative.org/sites/default/ files/publications/EfD\%20DP\%2020-18\%20June\%2016\% 202020_0.pdf.

Anim, D. O., \& Ofori-Asenso, R. (2020). Water scarcity and COVID-19 in sub-Saharan Africa. The Journal of Infection, 81(2), e108-e109.

Bendavid, et al. (2020). COVID-19 antibody seroprevalence in Santa Clara County, California. Retrieved July 15, 2020, from https://medrxiv.org/content/10.1101/2020.04.14. 20062463v1.full.pdf.

Birchall, G. (2020). WHO can we trust? Just when coronavirus gave the World Health Organization its moment to shine, it bottled it. Retrieved July 15, 2020, from https://rt.com/oped/485155-who-covid-global-panic/.

Boretti, A. (2020a). Covid 19 impact on atmospheric $\mathrm{CO}_{2}$ concentration. International Journal of Global Warming, 21(3), 317-323. https://doi.org/10.1504/IJGW.2020. 108686.

Boretti, A. (2020b). After less than 2 months, the simulations that drove the world to strict lockdown appear to be wrong, the same of the policies they generated. Health Services Research and Managerial Epidemiology, 7, 1-11. https:// doi.org/10.1177/2333392820932324.

Boretti, A. (2020c). Sustainable post Covid19 lockdown strategy through evidence-based policy: Analysis of Covid19 fatalities across Europe. Integrative Journal of Medical Sciences. https://doi.org/10.15342/ijms.7.172.

Boretti, A. (2020d). Analysis of the Charles De Gaulle aircraft carrier Covid19 epidemic: Infectivity and fatality in the young, healthy, active population-Lesson from the Charles de Gaulle aircraft carrier Covid19 experience. Integrative Journal of Medical Sciences. https://doi.org/10. 15342/ijms.7.174. 
Boretti, A. (2020e). Covid19 fatality rate for Saudi Arabia updated June 3, 2020. Journal of Global Antimicrobial Resistance. https://doi.org/10.1016/j.jgar.2020.07.014.

Boretti, A., Castelletto, S., Nayfeh, J., \& Al-Kouz, W. (2020). The energy future of Saudi Arabia. In E3S web conference (Vol. 181, p. 03005). https://doi.org/10.1051/e3sconf/ 202018103005.

Boretti, A., \& Rosa, L. (2019). Reassessing the projections of the world water development report. npj Clean Water, 2(1), 15.

Boulding, K. E. (1973). United States. Congress. House Energy reorganization act of 1973: Hearings, ninety-third congress, first session, on H.R. 11510 (p. 248).

Campbell, M. (2012). Why the silence on population? In P. Cafaro \& E. Crist (Eds.), Life on the brink: Environmentalists confront overpopulation (pp. 41-55). Bogart, GA: University of Georgia Press.

Comas-Herrera, A., Zalakain, J., Litwin, C., Hsu, A. T., \& Fernandez-Plotka, J.-L. (2020). Mortality associated with COVID-19 outbreaks in care homes: early international evidence, 17 April 2020. Article in LTCcovid.org, International Long-Term Care Policy Network, CPEC-LSE. Retrieved July 15, 2020, from https://ltccovid.org/2020/04/ 12 /mortality-associated-with-covid-19-outbreaks-in-carehomes-early-international-evidence/.

Committee for the Abolition of Illegitimate Debt (CADTM). (2002). Colombia and the IMF: Policies that worsen problems. Retrieved July 15, 2020, from https://cadtm.org/ Colombia-and-the-IMF-Policies-that.

Day, M. (2020). Covid-19: Four fifths of cases are asymptomatic, China figures indicate. BMJ. https://doi.org/10. 1136/bmj.m1375.

Duffin, E. (2020). Impact of the coronavirus pandemic on the global economy: Statistics \& facts. Retrieved July 15, 2020, from https://statista.com/topics/6139/covid-19impact-on-the-global-economy/.

Enjuanes, L., DeDiego, M. L., Álvarez, E., Deming, D., Sheahan, T., \& Baric, R. (2008). Vaccines to prevent severe acute respiratory syndrome coronavirus-induced disease. Virus Research, 133(1), 45-62.

Ferguson, N. M., et al. (2020). Report 9: Impact of non-pharmaceutical interventions (NPIs) to reduce COVID19 mortality and healthcare demand. Preprint at Spiral. https://doi.org/10.25561/77482.

Feuer, W. (2020). Coronavirus: The hit to the global economy will be worse than SARS. Retrieved July 15, 2020, from https://cnbc.com/2020/02/06/coronavirus-the-hit-to-theglobal-economy-will-be-worse-than-sars.html.

Fink, S. (2020). Worst-case estimates for U.S. coronavirus deaths. Retrieved July 15, 2020, from https://nytimes.com/ 2020/03/13/us/coronavirus-deaths-estimate.html.

Frölicher, T. L., Winton, M., \& Sarmiento, J. L. (2014). Continued global warming after $\mathrm{CO}_{2}$ emissions stoppage. $\mathrm{Na}$ ture Climate Change, 4(1), 40-44.

GAVI. (2017). Gavi welcomes election of new WHO Chief. Retrieved July 15, 2020, from https://gavi.org/gaviwelcomes-election-of-new-who-chief.

Haddout, S., Hoguane, A. M., Priya, K. L., \& Ljubenkov, I. (2020a). Water shortages and pandemics in Africa. The Round Table. https://doi.org/10.1080/00358533.2020. 1790784.
Haddout, S., Priya, K. L., Hoguane, A. M., \& Ljubenkov, I. (2020b). Water scarcity: A big challenge to slums in Africa to fight against COVID-19. Science \& Technology Libraries. $\quad$ https://doi.org/10.1080/0194262X.2020. 1765227.

Hildyard, N. (2019). Scarcity, 'polite society' and activism. Geoforum, 101, 294-298.

Intergovernmental Panel on Climate Change (IPCC). (2014). Climate change 2014: Synthesis report. Contribution of working groups I, II, and III to the fifth assessment report of the intergovernmental panel on climate change [Core Writing Team, R. K. Pachauri, \& L. A. Meyer (eds.)]. IPCC, Geneva, Switzerland, 151 pp. Retrieved July 15, 2020, from https://ipcc.ch/site/assets/uploads/2018/02/ SYR_AR5_FINAL_full.pdf.

International Energy Agency. (2019). World energy outlook 2019. Retrieved July 15, 2020, from https://iea.org/reports/ world-energy-outlook-2019.

International Monetary Fund (IMF). (2020). World economic outlook, April 2020-Chapter 1: The great lockdown. Retrieved July 15, 2020, from https://imf.org/en/ Publications/WEO.

Istituto Superiore di Sanità. (2020). Caratteristiche dei pazienti deceduti positivi all'infezione da SARS-CoV-2 in Italia. Retrieved July 15, 2020, from https://epicentro.iss.it/ coronavirus/sars-cov-2-decessi-italia.

Jackson, T. (2009). Prosperity without growth: Economics for a finite planet. London: Earthscan.

Jaffee, D., \& Case, R. A. (2018). Draining us dry: Scarcity discourses in contention over bottled water extraction. Local Environment, 23(4), 485-501.

Karunananthan, M. (2019). Can the human right to water disrupt neoliberal water policies in the era of corporate policymaking? Geoforum, 98, 244-253.

Kermack, W. O., \& McKendrick, A. G. (1927). A contribution to the mathematical theory of epidemics. A contribution to the mathematical theory of epidemics. Proceedings of the Royal Society of London, 115(772), 700-721.

Knutti, R., \& Rogelj, J. (2015). The legacy of our $\mathrm{CO}_{2}$ emissions: A clash of scientific facts, politics, and ethics. Climatic Change, 133(3), 361-373.

Kopnina, H., \& Washington, H. (2016). Discussing why population growth is still ignored or denied. Chinese Journal of Population Resources and Environment, 14(2), 133-143.

Mbaye, S., \& Moreno Badia, M. (2019). New data on global debt. Retrieved July 15, 2020, from https://blogs.imf.org/ 2019/01/02/new-data-on-global-debt/.

Meadows, D. H., \& Meadows, D. (2007). The history and conclusions of the limits to growth. System Dynamics Review: The Journal of the System Dynamics Society, 23(2-3), 191-197.

Mehta, L., Huff, A., \& Allouche, J. (2019). The new politics and geographies of scarcity. Geoforum, 101, 222-230.

Moreno Badia, M., \& Dudine, P. (2019). New data on world debt: A dive into country numbers. Retrieved July 15, 2020, from https://blogs.imf.org/2019/12/17/new-data-onworld-debt-a-dive-into-country-numbers/.

niid.go.jp. (2020). Field briefing: Diamond princess COVID-19 cases. Retrieved July 15, 2020, from https://niid.go.jp/niid/ en/2019-ncov-e/9407-covid-dp-fe-01.html. 
Nuki, P. (2020). The terrifying data behind the government's sudden coronavirus lockdown. Retrieved July 15, 2020, from https://telegraph.co.uk/global-health/science-anddisease/terrifying-data-behind-government-coronaviruslockdown/.

off-guardian.org. (2020a). 12 experts questioning the coronavirus panic. Retrieved July 15, 2020, from https://off-guardian.org/ 2020/03/24/12-experts-questioning-the-coronavirus-panic/.

off-guardian.org. (2020b). 10 more experts criticising the coronavirus panic. Retrieved July 15, 2020, from https:// off-guardian.org/2020/03/28/10-more-experts-criticising-thecoronavirus-panic/.

Oke, J., \& Heneghan, C. (2020). Oxford Covid19 evidence center. Updated 20 April 2020. Retrieved July 15, 2020, from https://cebm.net/covid-19/global-covid-19-casefatality-rates/.

O’Neill, B. C., Dalton, M., Fuchs, R., Jiang, L., Pachauri, S., \& Zigova, K. (2010). Global demographic trends and future carbon emissions. Proceedings of the National Academy of Sciences, 107, 17521-17526.

Pardi, N., Hogan, M. J., Porter, F. W., \& Weissman, D. (2018). mRNA vaccines-A new era in vaccinology. Nature Reviews Drug Discovery, 17(4), 261.

Patel, N. (2018). Figure of the week: Understanding poverty in Africa. Retrieved July 15, 2020, from https://brookings. edu/blog/africa-in-focus/2018/11/21/figure-of-the-weekunderstanding-poverty-in-africa/.

Peacock, S. H. (2018). Effect of ecosystem literacy on understanding the impact of human population growth on the environment: A multiple case study. Ecopsychology, 10(3), 181-188.

Pielke, R. A. (2013). Mesoscale meteorological modeling (3rd ed.). New York: Academic Press.

Pielke, R., Sr., Beven, K., Brasseur, G., Calvert, J., Chahine, M., Dickerson, R. R., et al. (2009). Climate change: The need to consider human forcings besides greenhouse gases. Eos, Transactions American Geophysical Union, 90(45), 413.

Pielke, R. A., Mahmood, R., \& McAlpine, C. (2016). Land's complex role in climate change. Physics Today, 69(2016), 40-46.

Roper, R. L., \& Rehm, K. E. (2009). SARS vaccines: Where are we? Expert Review of Vaccines, 8(7), 887-898.

Roser, M., Ritchie, H., \& Ortiz-Ospina, E. (2020). Coronavirus disease (COVID-19): Statistics and research. Retrieved July 15, 2020, from https://ourworldindata.org/ coronavirus.

RT.com. (2020). WHO says hydroxychloroquine trials for Covid-19 will RESUME as doubts emerge over side-effects research. Retrieved July 15, 2020, from https://rt. com/news/490668-who-hydroxychloroquine-trialsresume-coronavirus/.

Salby, M. L. (2012). Physics of the atmosphere and climate. Cambridge: Cambridge University Press.

Schmidt, J. J., \& Matthews, N. (2018). From state to system: Financialization and the water-energy-food-climate nexus. Geoforum, 91, 151-159.

Scoones, I., Smalley, R., Hall, R., \& Tsikata, D. (2019). Narratives of scarcity: Framing the global land rush. Geoforum, 101, 231-241.

Sinkins, J. D. (2020). French carrier surpasses Theodore Roosevelt with over 1,000 confirmed cases of COVID-19.
Retrieved July 15, 2020, from https://navytimes.com/news/ your-navy/2020/04/20/french-carrier-surpasses-theodoreroosevelt-with-over-1000-confirmed-cases-of-covid-19/.

smartwatermagazine.com. (2020). Desalination in Saudi Arabia. Retrieved July 15, 2020, from https://smartwatermagazine. com/specials/desalination-saudi-arabia.

Solanki, S. K., \& Krivova, N. A. (2003). Can solar variability explain global warming since 1970? Journal of Geophysical Research: Space Physics, 108(A5), JA009753. https:// doi.org/10.1029/2002JA009753.

Solanki, S. K., Usoskin, I. G., Kromer, B., Schüssler, M., \& Beer, J. (2004). Unusual activity of the Sun during recent decades compared to the previous 11,000 years. Nature, 431(7012), 1084-1087.

Steil, B. (2013). The Battle of Bretton Woods: John Maynard Keynes, Harry Dexter White, and the making of a new world order. Princeton: Princeton University Press.

Swiss Propaganda Research. (2020). Covid-19: A report from Italy. Retrieved July 15, 2020, from https://swprs.org/ covid-19-a-report-from-italy/.

Takouleu, J. M. (2020). AFRICA: Desalination, now a key component of water supply strategies. Retrieved July 15 , 2020, from https://afrik21.africa/en/africa-desalinationnow-a-key-component-of-water-supply-strategies/.

To, K. K. W., Tsang, O. T. Y., Leung, W. S., Tam, A. R., Wu, T. C., Lung, D. C., et al. (2020). Temporal profiles of viral load in posterior oropharyngeal saliva samples and serum antibody responses during infection by SARS-CoV-2: An observational cohort study. The Lancet Infectious Diseases, 20(5), 565-574.

United Nations Conference for Trade and Development. (2018). Economic development in Africa: Migration for structural transformation. Retrieved July 15, 2020, from https://unctad. org/en/Pages/ALDC/Africa/EDAR2018-Key-Statistics.aspx.

United Nations Department of Economic and Social Affairs. (2020). COVID-19 likely to shrink global GDP by almost one per cent in 2020. Retrieved July 15, 2020, from https:// un.org/sustainabledevelopment/blog/2020/04/covid-19-likelyto-shrink-global-gdp-by-almost-one-per-cent-in-2020/.

United Nations Water. (2018). World water development report 2018. Retrieved July 15, 2020, from https://unwater.org/ publications/world-water-development-report-2018/.

United Nations Water. (2019). World water development report 2019. Retrieved July 15, 2020, from https://unwater.org/ publications/world-water-development-report-2019/.

United States Center for Disease Control (US CDC). (2016). 2014-2016 Ebola outbreak in West Africa. Retrieved July 15, 2020, from https://cdc.gov/vhf/ebola/history/20142016-outbreak/cost-of-ebola.html.

United States Centers for Disease Control and Prevention (US CDC). (2020). Estimated influenza illnesses, medical visits, hospitalizations, and deaths in the United States: 2018-2019 influenza season. Retrieved July 15, 2020, from https://cdc.gov/flu/about/burden/2018-2019.html.

Usoskin, I. G., Solanki, S. K., Schüssler, M., Mursula, K., \& Alanko, K. (2003). Millennium-scale sunspot number reconstruction: Evidence for an unusually active Sun since the 1940s. Physical Review Letters, 91(21), 211101.

Wölfel, R., Corman, V. M., Guggemos, W., Seilmaier, M., Zange, S., Müller, M. A., et al. (2020). Virological 
assessment of hospitalized patients with COVID-2019. Nature, 581(7809), 465-469.

World Bank. (2020). COVID-19 (coronavirus) drives sub-Saharan Africa toward first recession in 25 years. Retrieved July 15, 2020, from https://worldbank.org/en/news/pressrelease/2020/04/09/covid-19-coronavirus-drives-sub-saharanafrica-toward-first-recession-in-25-years.

World Health Organization (WHO). (2019a). Middle East respiratory syndrome coronavirus (MERS-CoV). Retrieved July 15, 2020, from https://who.int/news-room/q-a-detail/ middle-east-respiratory-syndrome-coronavirus-(mers-cov).

World Health Organization (WHO). (2019b). WHO programmatic and financial reports for2018-2019, including audited financialstatements for 2018. Retrieved July 15, 2020, from https://who.int/about/finances-accountability/reports/ A72_INF5en.pdf?ua=1.

World Health Organization (WHO). (2020a). Immunity passports" in the context of COVID-19. Retrieved July 15, 2020, from https://who.int/news-room/commentaries/ detail/immunity-passports-in-the-context-of-covid-19.
World Health Organization (WHO). (2020b). More than 150 countries engaged in COVID-19 vaccine global access facility. Retrieved July 15, 2020, from https://who.int/ news-room/detail/15-07-2020-more-than-150-countriesengaged-in-covid-19-vaccine-global-access-facility.

Worldometer. (2020). COVID-19 coronavirus pandemic. Retrieved July 15, 2020, from https://worldometers.info/ coronavirus/?.

Wu, F., Wang, A., Liu, M., Wang, Q., Chen, J., Xia, S., Ling, Y., Zhang, Y., Xun, J., Lu, L., Jiang, S., Lu, H., Wen, Y., \& Huang, J. (2020). Neutralizing antibody responses to SARS-CoV-2 in a COVID-19 recovered patient cohort and their implications (3/28/2020). SSRN: ssrn.com/abstract $=3566211$ or https://doi.org/10.2139/ssrn.3566211.

Publisher's Note Springer Nature remains neutral with regard to jurisdictional claims in published maps and institutional affiliations. 